\title{
Reactivity of Triethylborane towards Di(alkyn-1-yl)(chloro)silanes. Competition between 1,1-Organoboration and 1,2-Hydroboration
}

\author{
Ezzat Khan, Stefan Bayer, and Bernd Wrackmeyer \\ Anorganische Chemie II, Universität Bayreuth, D-95440 Bayreuth, Germany \\ Reprint requests to Prof. Dr. B. Wrackmeyer. E-mail: b.wrack@uni-bayreuth.de
}

Z. Naturforsch. 2009, 64b, 47-57; received October 28, 2008

Dedicated to Professor Otto J. Scherer on the occasion of his $75^{\text {th }}$ birthday

Reactions of di(alkyn-1-yl)(chloro)silanes, $\mathrm{HSi}(\mathrm{Cl})(\mathrm{C} \equiv \mathrm{C}-\mathrm{R})_{2}, \mathrm{R}^{1} \mathrm{Si}(\mathrm{Cl})(\mathrm{C} \equiv \mathrm{C}-\mathrm{R})_{2}$ or $\mathrm{HSi}(\mathrm{Cl})-$ $(\mathrm{C} \equiv \mathrm{C}-\mathrm{R}) \mathrm{C} \equiv \mathrm{C}-\mathrm{R}^{\prime}$, with an excess of triethylborane, $\mathrm{BEt}_{3}$, proceed slowly (several days) at $100-$ $120{ }^{\circ} \mathrm{C}$. Twofold 1,1-organoboration of $\mathrm{HSi}(\mathrm{Cl})(\mathrm{C} \equiv \mathrm{C}-\mathrm{R})_{2}$ or $\mathrm{HSi}(\mathrm{Cl})(\mathrm{C} \equiv \mathrm{C}-\mathrm{R}) \mathrm{C} \equiv \mathrm{C}-\mathrm{R}^{\prime}$ leads to siloles, independent of $\mathrm{R}={ }^{n} \mathrm{Bu},{ }^{t} \mathrm{Bu}, \mathrm{SiMe}_{3}$. This provides the most straightforward way to siloles bearing both a hydrogen and a chlorine at the silicon atom. However, in the cases of $\mathrm{R}=\mathrm{Ph}, \mathrm{BEt}_{3}$ acts as 1,2-hydroborating reagent in the intermolecular first step of the reaction, leading to 1-silacyclobutene derivatives. All siloles and 1-silacyclobutene derivatives were characterized by multinuclear NMR spectroscopy $\left({ }^{1} \mathrm{H},{ }^{11} \mathrm{~B},{ }^{13} \mathrm{C}\right.$ and $\left.{ }^{29} \mathrm{Si}\right)$. Comparable 1-silacyclobutene derivatives were formed using 9-borabicyclo[3.3.1]nonane, 9-BBN, as a well established 1,2- hydroborating reagent.

Key words: Triethylborane, Siloles, Silacyclobutene, Hydroboration, Organoboration, NMR

\section{Introduction}

Triethylborane, $\mathrm{BEt}_{3}$, is a commercial reagent and has found widespread applications [1]. In our studies on 1,1-organoboration [2], $\mathrm{BEt}_{3}$ has been extensively used for 1,1-ethylboration reactions of alkyn1-yl metal derivatives to form new $\mathrm{C}-\mathrm{C}$ bonds, both for the synthesis of non-cyclic and cyclic compounds. Among the latter, a variety of siloles [2-6] became readily accessible [Scheme 1(a)], circumventing other much more tedious synthetic procedures. These particular 1,1-organoboration reactions require prolonged periods (several days) of heating at elevated temperature $\left(100-120{ }^{\circ} \mathrm{C}\right)$ and proceed in two steps. The first step involves intermolecular 1,1-ethylboration, followed in the second step by intramolecular 1,1-vinylboration. Triethylborane, $\mathrm{BEt}_{3}$, has been considered as thermally stable [7-12], and 1,2-dehydroboration, leading to the in situ formation of $\mathrm{Et}_{2} \mathrm{BH}$ and elimination of ethene, has never been observed, in contrast with many other trialkylboranes $[7,11,12]$. Recently we have explored the influence of $\mathrm{Si}-\mathrm{Cl}$ functions in alkyn-1-yl(chloro)silanes on the course of 1,1-ethylboration reactions. It has been shown that reactions of $\mathrm{BEt}_{3}$ with some alkyn-1-yl(trichloro)silanes [13] and alkyn-1-yl(dichloro)silanes [14] afford exclusively alkenes via 1,2-hydroboration instead

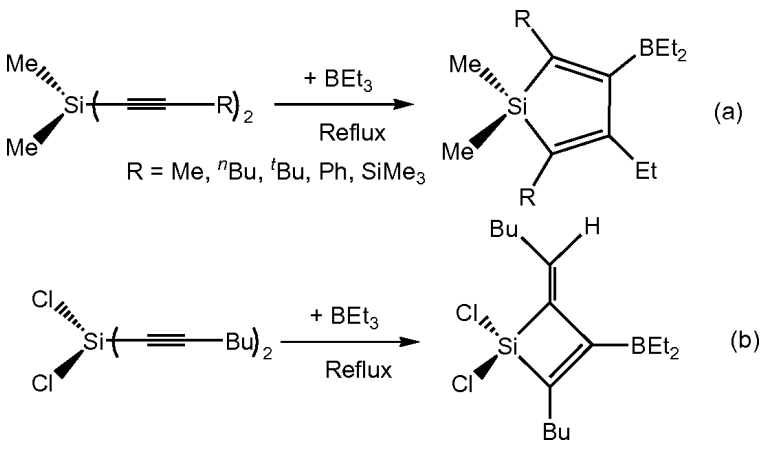

Scheme 1. Formation of silole (a) or 1-silacyclobutene derivatives (b) using $\mathrm{BEt}_{3}$.

of alkenes expected for 1,1-ethylboration. Moreover, di(alkyn-1-yl)(dichloro)silanes react with $\mathrm{BEt}_{3}$ to give 1-silacyclobutene derivatives [13] as the result of consecutive 1,2-hydroboration and intramolecular 1,1-vinylboration [Scheme 1(b)].

In this work, we report on the reactivity of di(alkyn1-yl)(chloro)silanes (Scheme 2) towards BEt 3 to study the potential competition between 1,1-ethylboration and 1,2-hydroboration. This study was expected to open the way to silole derivatives with hitherto unknown substituent patterns, and also to shed some light on mechanistic implications. The potential 1,2-hydroboration activity of $\mathrm{BEt}_{3}$ was confirmed by compar- 


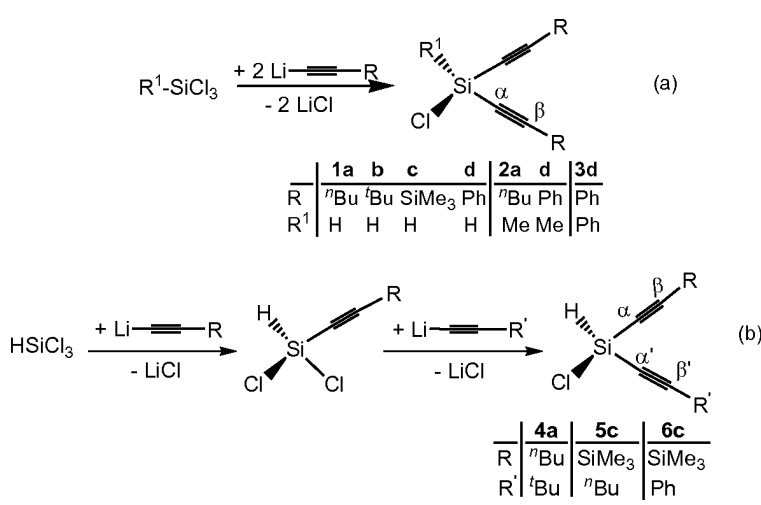

Scheme 2. Syntheses of di(alkyn-1-yl)(chloro)silanes as starting materials.

ison with analogous reactions using the well established 1,2-hydroborating reagent 9-borabicyclo[3.3.1]nonane, 9-BBN. Multinuclear NMR spectroscopy $\left({ }^{1} \mathrm{H}\right.$, ${ }^{11} \mathrm{~B},{ }^{13} \mathrm{C}$ and ${ }^{29} \mathrm{Si}$ ) served for monitoring all reactions and characterization of the final products.

\section{Results and Discussion}

\section{Synthesis of di(alkyn-1-yl)(chloro) silanes 1 - 6}

The di(alkyn-1-yl)(chloro)silanes bearing identical [1-3; Scheme 2(a)] or different $\mathrm{C} \equiv \mathrm{C}-\mathrm{R}$ groups [46; Scheme 2(b)] were prepared by the reactions of the respective trichlorosilane $\mathrm{R}^{1} \mathrm{SiCl}_{3}$ with the alkynyl lithium reagents following the literature procedure [15]. Pure samples of silanes $\mathbf{1 - 6}$ were obtained by fractional distillation. Although some of the di(alkyn-1-yl)(chloro)silanes have already been described [16], fairly complete NMR data sets were missing. Therefore, the NMR data of $\mathbf{1 - 6}$ were collected (Table 1 and Experimental Section).

\section{Formation of siloles: Reactions of di(alkyn-1-yl)} (chloro) silanes $1 \boldsymbol{a}-\boldsymbol{c}, 2 \boldsymbol{a}, \mathbf{4 a}, \mathbf{5 c}$, and $\mathbf{6 c}$ with $\mathrm{BEt}_{3}$

The reaction of the silane $\mathbf{1 a}$ with $\mathrm{BEt}_{3}$, carried out at $110-120{ }^{\circ} \mathrm{C}$, affords selectively the silole 7a. The analogous products (7b and $\mathbf{7 c}$ ) are observed for $\mathrm{R}=$ ${ }^{t} \mathrm{Bu}$ and $\mathrm{SiMe}_{3}$ (Scheme 3). The reaction of $\mathbf{1 d}$ with $\mathrm{BEt}_{3}$ gives a mixture of products. The NMR data (Tables 2 and 3 ) indicate the presence of the silole $7 \mathbf{d}$ and a 1-silacyclobutene (vide infra) as major components (40-45\% each) along with several unidentified side products (ca. 15\%). The same reactions were carried out under identical reaction conditions with $\mathbf{2 a}$ and $\mathbf{3 a}$. The NMR spectra of the reaction solutions (Table 2
Table $1 .{ }^{13} \mathrm{C}$ and ${ }^{29} \mathrm{Si} \mathrm{NMR}$ data ${ }^{\mathrm{a}}$ of di(alkyn-1-yl)(chloro)silanes $\mathbf{1}-\mathbf{6}$.

\begin{tabular}{llcl}
\hline & $\delta^{13} \mathrm{C}(\equiv \mathrm{C})$ & $\delta^{13} \mathrm{C}(\mathrm{Si}-\mathrm{C} \equiv)$ & $\delta^{29} \mathrm{Si}$ \\
\hline $\mathbf{1 a}^{\mathrm{b}}$ & $112.5[25.9]$ & $77.4[125.8]$ & -57.5 \\
$\mathbf{1} \mathbf{b}^{\mathrm{c}}$ & $120.1[25.1]$ & $75.6[125.4]$ & -56.5 \\
$\mathbf{1 c}^{\mathrm{d}}$ & $120.4[20.0][71.5]$ & $103.3[114.0][11.5]$ & -60.1, \\
& & & $-16.3\{2.1\}^{1}$ \\
$\mathbf{1 d}^{\mathrm{e}}$ & $109.5[25.5]$ & $85.5[124.3]$ & -55.4 \\
$\mathbf{2} \mathbf{a}^{\mathrm{f}}$ & $110.8[24.9]$ & $80.1[122.8]$ & -34.9 \\
$\mathbf{2 c}^{\mathrm{g}}$ & $108.1[24.5]$ & $88.3[121.3]$ & -32.7 \\
$\mathbf{3} \mathbf{c}^{\mathrm{h}}$ & $109.6[25.2]$ & $87.2[126.1]$ & -42.0 \\
$\mathbf{4} \mathbf{a}^{\mathrm{i}}$ & $112.6[26.3, \beta]$, & $77.4[126.3, \alpha]$, & -57.1 \\
& $119.8[24.7, \beta]$ & $75.5[125.2, \alpha]$ & \\
$\mathbf{5} \mathbf{c}^{\mathrm{j}}$ & $113.4[26.1, \beta]$, & $76.7[126.8, \alpha]$, & $-58.8,-16.4$ \\
& $119.4[19.7][70.8, \beta]$ & $104.2[114.7][11.6, \alpha]$ \\
$\mathbf{6 c}^{\mathrm{k}}$ & $109.4[25.8, \beta]$, & $85.2[124.2, \alpha], 103.4$ & -58.0, \\
& & & $-16.3\{2.3\}^{1}$ \\
& $120.3[20.0][71.6, \beta][114.4][11.6, \alpha]$ & \\
\hline
\end{tabular}

${ }^{\text {a }}$ Measured in $\mathrm{C}_{6} \mathrm{D}_{6}$; coupling constants $J\left({ }^{13} \mathrm{C},{ }^{29} \mathrm{Si}\right)[ \pm 0.4 \mathrm{~Hz}]$ are given in square brackets; ${ }^{\mathrm{b}}$ other ${ }^{13} \mathrm{C}$ data: $\delta=30.1,22.1,19.7$, $13.6\left({ }^{n} \mathrm{Bu}\right) ;{ }^{\mathrm{c}}$ other ${ }^{13} \mathrm{C}$ data: $\delta=30.1,28.3\left({ }^{t} \mathrm{Bu}\right) ;{ }^{\mathrm{d}}$ other ${ }^{13} \mathrm{C}$ data: $\delta\left[J\left({ }^{13} \mathrm{C},{ }^{29} \mathrm{Si}\right)\right]=-1.0\left[56.6, \mathrm{SiMe}_{3}\right] ; \quad{ }^{\mathrm{e}}$ other ${ }^{13} \mathrm{C}$ data: $\delta=$ $121.3,128.5,132.6,130.1(i, o, m, p, \mathrm{Ph}) ; \quad{ }^{\mathrm{f}}$ other ${ }^{13} \mathrm{C}$ data: $\delta$ $\left[{ }^{1} J\left({ }^{13} \mathrm{C}{ }^{29} \mathrm{Si}\right)\right]=5.1\left[73.7\right.$, Si-Me], 30.2, 22.1, 19.6, $13.6\left({ }^{n} \mathrm{Bu}\right)$; g other ${ }^{13} \mathrm{C}$ data: $\delta\left[{ }^{1} J\left({ }^{13} \mathrm{C},{ }^{29} \mathrm{Si}\right)\right]=4.6[74.8, \mathrm{Si}-\mathrm{Me}], 121.8,132.6$, $128.5,129.8(i, o, m, p, \mathrm{Ph}) ;{ }^{\mathrm{h}}$ other ${ }^{13} \mathrm{C}$ data: $\delta\left[{ }^{1} J\left({ }^{13} \mathrm{C},{ }^{29} \mathrm{Si}\right)\right]=$ 132.6 [99.7], 134.4, 128.7, 131.8 (i, o, $m, p, \mathrm{Si}-\mathrm{Ph}$ ), 121.5, 132.7, $128.5,130.0(i, o, m, p, \mathrm{Ph}) ; \quad \mathrm{i}$ other ${ }^{13} \mathrm{C}$ data: $\delta=13.6,19.6,22.0$, $29.9\left({ }^{n} \mathrm{Bu}\right), 28.4,30.1\left({ }^{t} \mathrm{Bu}\right) ; \quad \mathrm{j}$ other ${ }^{13} \mathrm{C}$ data: $\delta\left[J\left({ }^{29} \mathrm{Si},{ }^{13} \mathrm{C}\right)\right]=$ -0.9 [56.6, $\mathrm{SiMe}_{3}$ ] $, 13.5,19.6,22.0,29.8\left({ }^{n} \mathrm{Bu}\right) ; \quad{ }^{\mathrm{k}}$ other ${ }^{13} \mathrm{C}$ data: $\delta=-0.9$ [56.6, $\mathrm{SiMe}_{3}$ ], 121.2, 128.5, 132.6, 130.1 (i, o, $\left.m, p, \mathrm{Ph}\right)$; ${ }^{1} J\left({ }^{29} \mathrm{Si},{ }^{29} \mathrm{Si}\right)$

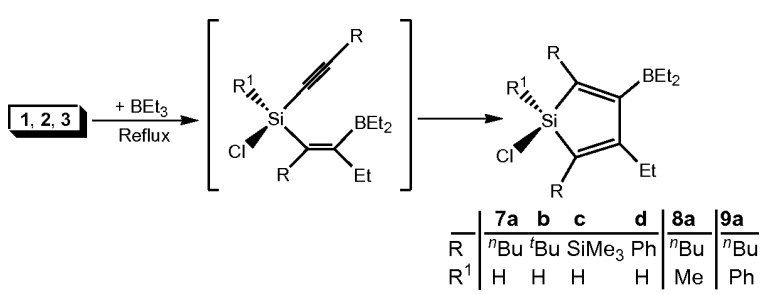

Scheme 3. Synthesis of siloles via 1,1-ethylboration of silanes $\mathbf{1}-\mathbf{3}$.

and e.g. Fig. 2) revealed the formation of the siloles $\mathbf{8 a}$ and $9 \mathbf{a}$.

The silanes 4-6 containing different alkyn-1-yl groups $\left[R \neq \mathrm{R}^{\prime}\right.$; Scheme 2(b)] were treated with $\mathrm{BEt}_{3}$ at $110-120{ }^{\circ} \mathrm{C}$. In the case of $\mathbf{4 a}, 1,1$-ethylboration of the $\mathrm{Si}-\mathrm{C} \equiv \mathrm{C}-{ }^{n} \mathrm{Bu}$ group occurs more readily than of the $\mathrm{Si}-\mathrm{C} \equiv \mathrm{C}-{ }^{t} \mathrm{Bu}$ unit (Fig. 3), and in the cases of $\mathbf{5 c}$ and $\mathbf{6 c}, 1,1$-ethylboration of the $\mathrm{Si}-\mathrm{C} \equiv \mathrm{C}-\mathrm{SiMe}_{3}$ units is preferred over $\mathrm{C} \equiv \mathrm{C}-{ }^{n} \mathrm{Bu}$ or $\mathrm{C} \equiv \mathrm{C}-\mathrm{Ph}$ groups (Scheme 4). This finding is supported by additional NMR data sets which can be assigned to siloles $13 \mathbf{a}^{\prime}, \mathbf{1 4} \mathbf{c}^{\prime}$ and $15 \mathbf{c}^{\prime}$, present in minor quantities. In addition to the mixture of 
Table $2 .{ }^{11} \mathrm{~B},{ }^{13} \mathrm{C}$ and ${ }^{29} \mathrm{Si} \mathrm{NMR}$ data ${ }^{\mathrm{a}}$ of siloles $\mathbf{7}-\mathbf{9}$ and $\mathbf{1 3 - 1 5}$.

\begin{tabular}{|c|c|c|c|c|c|c|}
\hline & $\delta^{13} \mathrm{C}(\mathrm{C}-2)$ & $\delta^{13} \mathrm{C}(\mathrm{C}-3)$ & $\delta^{13} \mathrm{C}(\mathrm{C}-4)$ & $\delta^{13} \mathrm{C}(\mathrm{C}-5)$ & $\delta^{29} \mathrm{Si}$ & $\delta^{11} \mathrm{~B}$ \\
\hline$\overline{7 a^{b}}$ & $135.3[73.1]$ & 169.1 (br) & $157.2[15.7]$ & $131.7[78.8]$ & -7.0 & 89.7 \\
\hline $7 b^{c}$ & $145.7[84.1]$ & 166.4 (br) & 156.7 [16.9] & 139.3 [76.9] & -5.8 & 87.5 \\
\hline $7 c^{d}$ & $139.9[48.3][63.3]$ & 186.9 (br) & $173.3[10.2][12.7]$ & $132.3[55.6][61.9]$ & $9.8,-10.2,-9.8$ & 87.1 \\
\hline $7 d^{e}$ & $141.9[79.5]$ & 172.1 (br) & $159.7[$ n. m.] & $136.2[\mathrm{n} . \mathrm{m}]$. & -6.6 & 86.7 \\
\hline $8 \mathbf{a}^{\mathrm{f}}$ & $136.6[72.5]$ & 167.1 (br) & $155.4[15.1]$ & $132.5[78.1]$ & 16.7 & 86.1 \\
\hline $9 \mathbf{a}^{g}$ & $136.6[73.6]$ & 169.0 (br) & $157.2[15.0]$ & $132.7[79.4]$ & 5.3 & 86.8 \\
\hline $13 \mathbf{a}^{\mathrm{h}}$ & $145.7[72.0]$ & 164.4 (br) & 155.3 [16.9] & $132.2[79.1]$ & -7.4 & 89.0 \\
\hline $13 \mathbf{a}^{\prime I}$ & 135.5 & 168.8 (br) & 157.7 & 139.3 & -5.6 & 89.0 \\
\hline $14 a^{j}$ & $143.4[69.2]$ & 169.3 (br) & $174.6[10.7]$ & $126.6[63.7]$ & 0.8 & 88.3 \\
\hline $15 c^{\mathrm{k}}$ & $144.3[70.2]$ & 170.7 (br) & $174.5[11.4][10.1]$ & $138.7[57.4][60.7]$ & 0.9 & 88.5 \\
\hline
\end{tabular}

${ }^{\text {a }}$ Measured in $\mathrm{C}_{6} \mathrm{D}_{6}$, coupling constants corresponding to ${ }^{1} J\left({ }^{13} \mathrm{C},{ }^{29} \mathrm{Si}\right)$ and ${ }^{2} J\left({ }^{13} \mathrm{C},{ }^{29} \mathrm{Si}\right)$ are given in square brackets, n. m. means not measured, (br) indicates a broad ${ }^{13} \mathrm{C}$ resonance signal of carbon linked to boron atom owing to partially relaxed ${ }^{11} \mathrm{~B}-{ }^{13} \mathrm{C}$ spin-spin scalar coupling [21]; $\quad{ }^{\mathrm{b}}$ other ${ }^{13} \mathrm{C}$ data: $\delta=14.2,23.4,27.7,33.7,34.2\left({ }^{n} \mathrm{Bu}\right), 9.0,22.1(\mathrm{br}), 22.6(\mathrm{br})\left(\mathrm{BEt}_{2}\right), 13.4,31.4(\mathrm{Et}) ; \quad{ }^{\mathrm{c}}$ other ${ }^{13} \mathrm{C}$ data: $\delta=32.5,32.7,26.7\left({ }^{t} \mathrm{Bu}\right), 9.9,22.7(\mathrm{br})\left(\mathrm{BEt}_{2}\right), 14.4,30.3(\mathrm{Et}) ; \quad \mathrm{d}$ other ${ }^{13} \mathrm{C}$ data: $\delta\left[J\left({ }^{13} \mathrm{C},{ }^{29} \mathrm{Si}\right)\right]=1.2[51.8, \mathrm{SiMe} 3], 1.3[52.3, \mathrm{SiMe}]$, 9.3, 9.3, 22.4 (br), 23.6 (br) $\left(\mathrm{BEt}_{2}\right), 14.8,30.2(\mathrm{Et})$; $\quad{ }^{\mathrm{e}}$ other ${ }^{13} \mathrm{C}$ data: $\delta=9.0,22.3\left(\mathrm{BEt}_{2}\right), 13.7,27.1$ (Et), Ph carbons without assignment; ${ }^{\mathrm{f}}$ other ${ }^{13} \mathrm{C}$ data: $\delta\left[\mathrm{J}\left({ }^{13} \mathrm{C},{ }^{29} \mathrm{Si}\right)\right]=0.8[69.5, \mathrm{Si}-\mathrm{Me}], 14.2,14.3,23.4,27.8,31.6,32.9,33.4\left({ }^{n} \mathrm{Bu}\right), 22.6(\mathrm{br}), 9.1(\mathrm{BEt}), 24.7,13.6(\mathrm{Et})$; ${ }^{\mathrm{g}}$ other ${ }^{13} \mathrm{C}$ are not assigned due to the presence of some side products including 1-silacyclobutene; ${ }^{\mathrm{h}}$ other ${ }^{13} \mathrm{C}$ data: $\delta=14.2,23.4,24.9$, 27.7, $33.6\left({ }^{n} \mathrm{Bu}\right), 26.8,32.7\left({ }^{t} \mathrm{Bu}\right), 9.8,22.1,22.6\left(\mathrm{BEt}_{2}\right), 13.7,35.5(\mathrm{Et}) ;{ }^{\mathrm{i}}$ other ${ }^{13} \mathrm{C}$ data: $\delta=14.4,23.5,25.2,27.0,34.1\left({ }^{n} \mathrm{Bu}\right), 26.4$, $32.4\left({ }^{t} \mathrm{Bu}\right), 9.1,22.2\left(\mathrm{BEt}_{2}\right), 13.5,34.5(\mathrm{Et}) ;{ }^{\mathrm{j}}$ other ${ }^{13} \mathrm{C}$ data: $\delta=1.3\left[52.9, \mathrm{SiMe}_{3}\right], 14.1,24.8,31.5,34.0\left({ }^{n} \mathrm{Bu}\right), 22.6,9.0(\mathrm{BEt} 2), 14.1$, $31.1(\mathrm{Et}) ; \quad{ }^{\mathrm{k}}$ other ${ }^{13} \mathrm{C}$ data: $\delta=1.2$ [52.3, $\left.\mathrm{SiMe}_{3}\right], 9.5,22.3\left(\mathrm{BEt}_{2}\right), 14.4,30.8(\mathrm{Et}), 128.1,128.6,127.9,126.8(i, o, m, p, \mathrm{Ph})$.

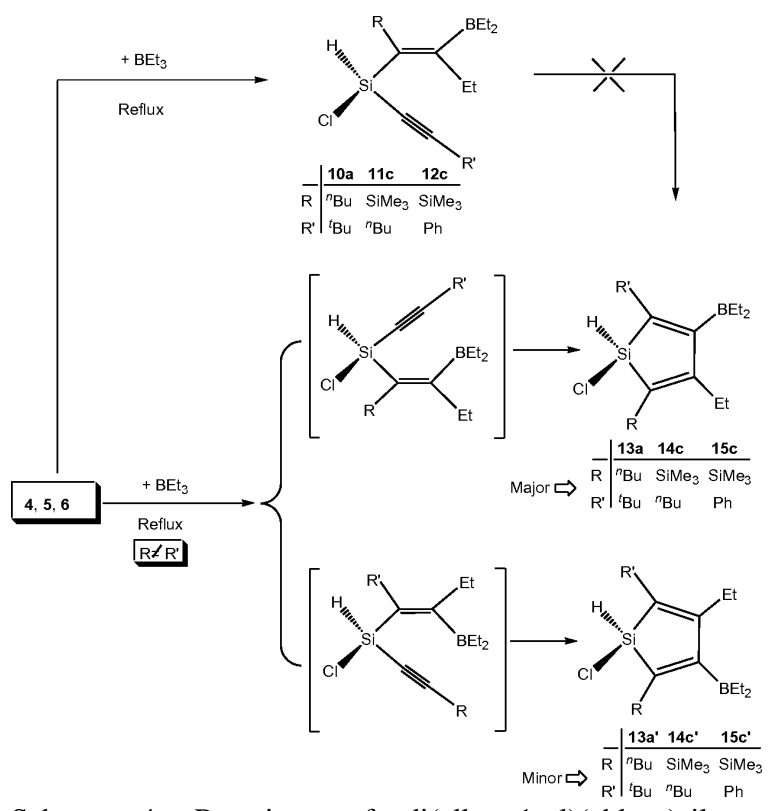

Scheme 4. Reactions of di(alkyn-1-yl)(chloro)silanes $\mathrm{H}(\mathrm{Cl}) \mathrm{Si}(\mathrm{C} \equiv \mathrm{C}-\mathrm{R}) \mathrm{C} \equiv \mathrm{C}-\mathrm{R}^{\prime} \mathbf{4}-\mathbf{6}\left(\mathrm{R} \neq \mathrm{R}^{\prime}\right)$ with $\mathrm{BEt}_{3}$ to afford mixtures of the respective siloles.

siloles, small amounts of the side products 10 12 (Scheme 4) are formed. These products are unsuitable to undergo ring closure via intramolecular 1,1-vinylboration. The desired siloles (13-15) are the main components in the reaction mixtures, identified unambiguously by their distinct NMR data.
The siloles bearing identical $(7 \mathbf{a}-\mathbf{d}, \mathbf{8 a}, \mathbf{9 a})$ or different (13a, 14c, 15c) substituents at 2 and 5 positions are oily, air and moisture sensitive compounds, and their structures were proposed on the basis of consistent sets of NMR data (Table 2 and Figs. 1, 2, 3).

\section{Formation of 1-silacyclobutene derivatives: Reactions of di(alkyn-1-yl)(chloro)silanes $\mathbf{1 d}, \mathbf{2 d}$ and $\mathbf{3 d}$ with $\mathrm{BEt}_{3}$}

The reaction of $\mathbf{1 d}$ with $\mathrm{BEt}_{3}$ gives the silole $\mathbf{7 d}$ together with a second major compound, subsequently identified as the 1-silacyclobutene derivative 16d. This result shows that 1,1-ethylboration can be accompanied by competitive reactions which, depending on various substituents, may become dominant, offering an attractive route to novel heterocycles, such as 1silacyclobutene derivatives. Therefore, the reactions of $\mathbf{2 d}$ and $\mathbf{3 d}$ with $\mathrm{BEt}_{3}$ are of interest (Scheme 5). NMR spectra of the reaction solutions indicate almost quantitative formation of 1-silacyclobutene derivatives (>90\%) instead of siloles. In the light of our previous

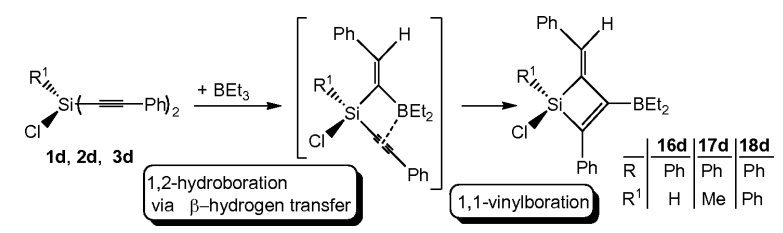

Scheme 5. Reactions of chlorodi(phenylethynyl)silanes 1d3d with $\mathrm{BEt}_{3}$ leading to 1-silacyclobutene derivatives. 
Table $3 .{ }^{11} \mathrm{~B},{ }^{13} \mathrm{C}$ and ${ }^{29} \mathrm{Si}$ NMR data ${ }^{\mathrm{a}}$ of alkenyl(alkyn-1-yl)silanes $\mathbf{1 9}$ and $\mathbf{2 0 .}$

\begin{tabular}{lllllll}
\hline & $\delta^{13} \mathrm{C}(\mathrm{BC}=)$ & $\delta^{13} \mathrm{C}(=\mathrm{C})$ & $\delta^{13} \mathrm{C}(\mathrm{Si}-\mathrm{C} \equiv)$ & $\delta^{13} \mathrm{C}(\equiv \mathrm{C})$ & $\delta^{11} \mathrm{~B}$ & $\delta^{29} \mathrm{Si}$ \\
\hline $\mathbf{1 9 a}^{\mathrm{b}}$ & $144.0[73.4, \mathrm{br}]$ & 162.2 & $82.9[104.9]$ & $110.7[21.1]$ & 81.9 & -15.6 \\
$\mathbf{1 9 d}^{\mathrm{c}}$ & $147.7[73.7, \mathrm{br}]$ & 156.3 & $91.8[103.9]$ & $108.2[20.5]$ & 83.6 & -14.6 \\
$\mathbf{2 0 d}^{\mathrm{d}}$ & $144.1[75.5, \mathrm{br}]$ & 158.7 & $90.2[109.0]$ & $109.3[21.3]$ & 84.6 & -23.7 \\
\hline
\end{tabular}

${ }^{\text {a }}$ Measured in $\mathrm{C}_{6} \mathrm{D}_{6}$, coupling constants $J\left({ }^{13} \mathrm{C},{ }^{29} \mathrm{Si}\right)[ \pm 0.4 \mathrm{~Hz}]$ are given in square brackets, (br) denotes a broad ${ }^{13} \mathrm{C}$ resonance signal as the result of partially relaxed scalar ${ }^{11} \mathrm{~B}-{ }^{13} \mathrm{C}$ spin-spin coupling $[21]$; ${ }^{\mathrm{b}}$ other ${ }^{13} \mathrm{C}$ data: $\delta\left[J\left({ }^{13} \mathrm{C}{ }^{29} \mathrm{Si}\right)\right]=6.2[64.6, \mathrm{Si}-\mathrm{Me}], 35.2,31.7,22.2$, 14.3 (=C-Bu), 30.5, 22.9, 19.9, 13.7 ( $\equiv \mathrm{C}-\mathrm{Bu}), 34.4,34.5,31.3(\mathrm{br}), 23.6(9-\mathrm{BBN}) ; \quad{ }^{\mathrm{c}}$ other ${ }^{13} \mathrm{C}$ data: $\delta\left[J\left({ }^{13} \mathrm{C},{ }^{29} \mathrm{Si}\right)\right]=5.1[65.9, \mathrm{Si}-\mathrm{Me}]$, 34.7, 34.7, 31.7 (br), 23.7 (9-BBN), 140.0, 132.5, 129.9, 129.5, 129.4, 128.6, 128.5, $122.5(\mathrm{Ph}) ; \quad{ }^{\mathrm{d}}$ other ${ }^{13} \mathrm{C}$ data: $\delta=34.7,34.6,31.9(\mathrm{br})$, 23.6 (9-BBN), 139.1, 135.5, 134.5, 134.3, 132.6, 132.4, 130.7, 130.3, 129.4, 129.0, 128.7, 122.3 (Ph, Si-Ph).

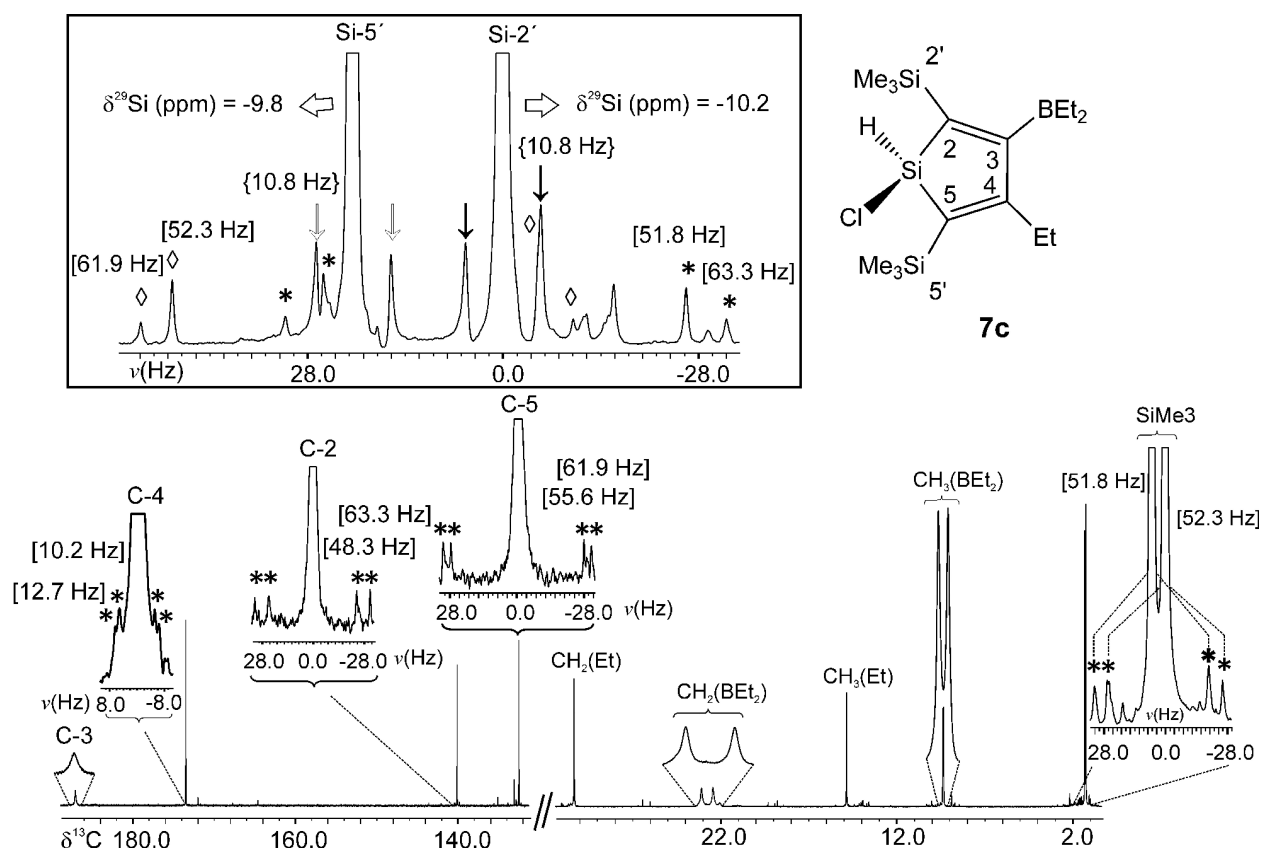

Fig. 1. $100.5 \mathrm{MHz}{ }^{13} \mathrm{C}\left\{{ }^{1} \mathrm{H}\right\}$ and $79.6 \mathrm{MHz}{ }^{29} \mathrm{Si}\left\{{ }^{1} \mathrm{H}\right\}$ (inserted) NMR spectra of 7c. In the ${ }^{13} \mathrm{C}$ NMR spectrum, the ${ }^{29} \mathrm{Si}$ satellites, marked by asterisks, correpond to ${ }^{1} J\left({ }^{13} \mathrm{C},{ }^{29} \mathrm{Si}\right)$ and ${ }^{n} J\left({ }^{13} \mathrm{C},{ }^{29} \mathrm{Si}\right), n \geq 2$. Note the typically broad signal belonging to the carbon atom bonded to boron [21]. In the ${ }^{29} \mathrm{Si}$ NMR spectrum, the respective ${ }^{13} \mathrm{C}$ satellites are marked by asterisks and diamonds, while ${ }^{29} \mathrm{Si}$ satellites, marked by arrows, correspond to ${ }^{2} J\left({ }^{29} \mathrm{Si},{ }^{29} \mathrm{Si}\right)$. The ${ }^{29} \mathrm{SiMe}_{3}$ nuclei $2^{\prime}$ and $5^{\prime}$ are precisely assigned based on these NMR data.

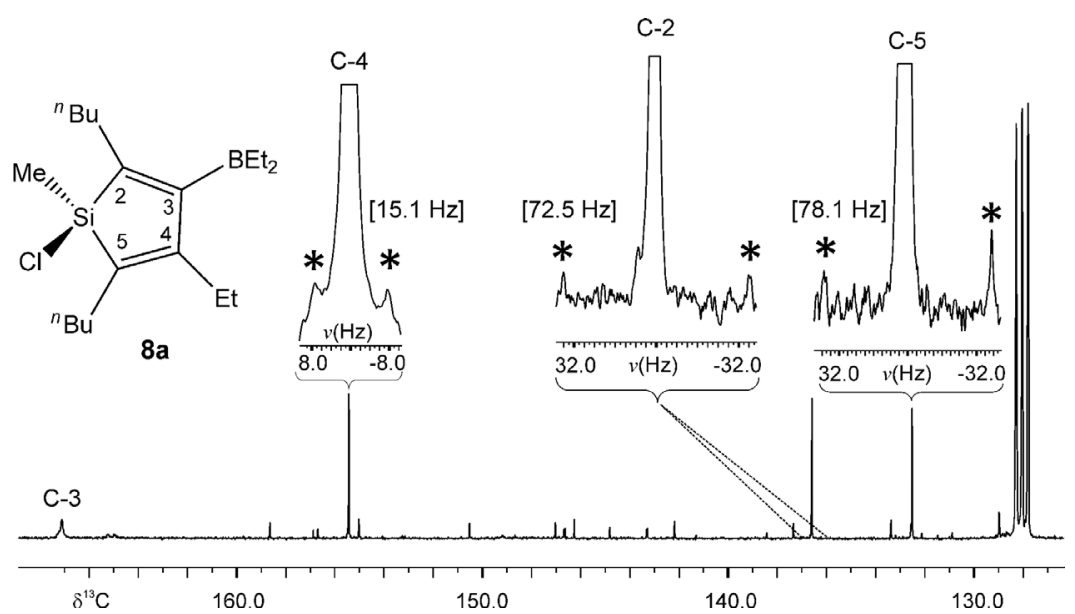

Fig. 2. Part of the $100.5 \mathrm{MHz}$ ${ }^{13} \mathrm{C}\left\{{ }^{1} \mathrm{H}\right\}$ NMR spectrum of a crude reaction mixture mainly containing 8a. Only ${ }^{13} \mathrm{C}$ signals belonging to the silole ring are shown. The ${ }^{29} \mathrm{Si}$ satellites, marked by asterisks, represent ${ }^{1} \mathrm{~J}\left({ }^{13} \mathrm{C},{ }^{29} \mathrm{Si}\right)$ and ${ }^{2} J\left({ }^{13} \mathrm{C},{ }^{29} \mathrm{Si}\right)$. Note the typically broad signal belonging to the carbon atom bonded to boron [21]. 
Table $4 .{ }^{11} \mathrm{~B},{ }^{13} \mathrm{C}$ and ${ }^{29} \mathrm{Si}$ NMR data ${ }^{\mathrm{a}}$ of 1-silacyclobutene derivatives $\mathbf{1 6}-\mathbf{1 8}, \mathbf{2 1}$ and $\mathbf{2 2}$.

\begin{tabular}{lllllrl}
\hline & $\delta^{13} \mathrm{C}(=\mathrm{CH})$ & $\delta^{13} \mathrm{C}(\mathrm{C}-2)$ & $\delta^{13} \mathrm{C}(\mathrm{C}-3)$ & $\delta^{13} \mathrm{C}(\mathrm{C}-4)$ & $\delta^{29} \mathrm{Si}$ & $\delta{ }^{11} \mathrm{~B}$ \\
\hline $\mathbf{1 6 d}^{\mathrm{b}}$ & n.a. & $141.9[\mathrm{n} .0]$. & $173.3(\mathrm{br})$ & $159.4[$ n.o.] & -16.4 & 86.7 \\
$\mathbf{1 7 d}^{\mathrm{c}}$ & 130.1 & $147.2[58.0]$ & $179.9(\mathrm{br})$ & $157.2[63.8]$ & 10.7 & 85.7 \\
$\mathbf{1 8 d}^{\mathrm{d}}$ & 134.4 & $146.2[58.8]$ & $182.8(\mathrm{br})$ & $156.3[63.6]$ & -1.2 & 86.9 \\
$\mathbf{2 1 a}^{\mathrm{e}}$ & $128.9[12.2]$ & $147.1[58.4]$ & $175.9(\mathrm{br})$ & $165.3[58.7]$ & 11.7 & 84.2 \\
$\mathbf{2 1 d}^{\mathrm{d}}$ & 131.0 & $147.8[57.9]$ & $177.8(\mathrm{br})$ & $161.0[61.1]$ & 11.0 & 86.8 \\
$\mathbf{2 2 d}^{\mathrm{g}}$ & 132.6 & $146.9[58.8]$ & $180.6(\mathrm{br})$ & $160.2[62.4]$ & -1.8 & 84.6 \\
\hline
\end{tabular}

a Measured in $\mathrm{C}_{6} \mathrm{D}_{6}$, coupling constants ${ }^{1} J\left({ }^{13} \mathrm{C},{ }^{29} \mathrm{Si}\right)$ and ${ }^{2} J\left({ }^{13} \mathrm{C},{ }^{29} \mathrm{Si}\right)$ are given in square brackets $[ \pm 0.4 \mathrm{~Hz}]$, (br) denotes a broad ${ }^{13} \mathrm{C}$ resonance signal as the result of partially relaxed scalar ${ }^{11} \mathrm{~B}-{ }^{13} \mathrm{C}$ coupling $[21]$; $\quad \mathrm{b}$ other carbons were not assigned, as silole accompanied by some other unknown side products are present; ${ }^{\mathrm{c}}$ other ${ }^{13} \mathrm{C}$ data: $\delta\left[J\left({ }^{13} \mathrm{C},{ }^{29} \mathrm{Si}\right)\right]=3.6[52.0, \mathrm{Si}-\mathrm{Me}], 21.6(\mathrm{br}), 9.0(\mathrm{BEt} 2), 139.0,137.3$, 129.3, 129.1, 128.9, 128.1, $127.9(\mathrm{Ph}) ; \quad{ }^{\mathrm{d}}$ other ${ }^{13} \mathrm{C}$ data: $\delta\left[J\left({ }^{13} \mathrm{C},{ }^{29} \mathrm{Si}\right)\right]=21.7(\mathrm{br}), 9.3\left(\mathrm{BEt}_{2}\right), 138.4$ [4.6], 136.9 [5.3], 134.3, 132.7, $132.5,130.3,129.3,128.9,128.9,128.2,128.0,127.1(\mathrm{Ph}) ;{ }^{\mathrm{e}}$ other ${ }^{13} \mathrm{C}$ data: $\delta\left[J\left({ }^{13} \mathrm{C},{ }^{29} \mathrm{Si}\right)\right]=3.4[49.8, \mathrm{Si}-\mathrm{Me}], 34.4,34.2,32.2(\mathrm{br})$, 23.4 (9-BBN); ${ }^{\mathrm{f}}$ other ${ }^{13} \mathrm{C}$ data: $\delta\left[J\left({ }^{13} \mathrm{C},{ }^{29} \mathrm{Si}\right)\right]=3.2$ [51.8, Si-Me], 34.4, 34.2, 32.2 (br), 23.4 (9-BBN), 139.1 [5.3], 137.7 [4.6], 131.1, $129.8,129.1,128.9,128.1,127.8(\mathrm{Ph}) ; \quad \mathrm{g}$ other ${ }^{13} \mathrm{C}$ data: $\delta\left[J\left({ }^{13} \mathrm{C},{ }^{29} \mathrm{Si}\right)\right]=34.5,34.3,32.4(\mathrm{br}), 23.5(9-\mathrm{BBN}), 138.7[5.3], 137.5[4.6]$, $132.7[71.1], 134.5,131.8,131.3,130.0,129.0,128.9,128.9,128.6,128.5(\mathrm{Ph})$.

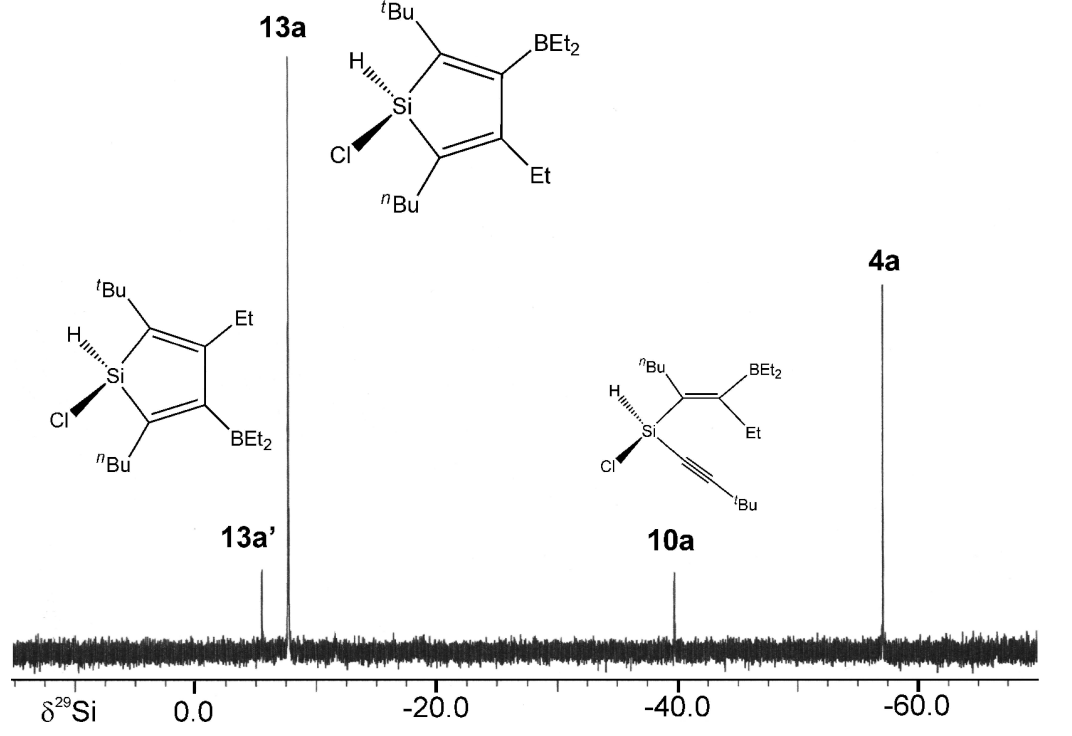

Fig. 3. $\quad 49.7 \mathrm{MHz}{ }^{29} \mathrm{Si} \quad \mathrm{NMR}$ spectrum (refocused INEPT) of the reaction mixture indicating starting silane 4a, alkeny(alkyn-1yl)silane 10a (as a side product) and the desired siloles 13a and in minor quantity 13a' (see Scheme 4). experience $[13,14]$, we propose that the first step of the reaction proceeds selectively via 1,2-hydroboration of one of the alkyn-1-yl groups of these silanes. The intermediate (not detected) bears the diethylboryl and the silyl groups at the same olefinic carbon atom. This is an ideal geometry for the rearrangement via intramolecular 1,1-vinylboration to give 1-silacyclobutene derivatives. Apparently, the presence of the phenyl group at the $\mathrm{C} \equiv \mathrm{C}$ bond, together with the $\mathrm{Si}-\mathrm{Cl}$ function, opens the way to 1,2-hydroboration instead of 1,1-ethylboration (Scheme 5).

We propose that this particular 1,2-hydroboration, unusual for $\mathrm{BEt}_{3}$, proceeds via $\beta$-hydrogen transfer [14] rather than via 1,2-dehydroboration after intermediate formation of $\mathrm{Et}_{2} \mathrm{BH}$. The phenyl group linked to the $\mathrm{C} \equiv \mathrm{C}$ bond is considered to stabilize a polar tran- sition state. The $\mathrm{Si}-\mathrm{Cl}$ function increases the strength of the $\mathrm{Si}-\mathrm{C} \equiv$ bond and hampers the cleavage of this bond as required in the course of 1,1-ethylboration. Monitoring of the reactions by ${ }^{29} \mathrm{Si}$ NMR spectroscopy (Fig. 4) proved helpful, and the solution-state structures of the final products could be deduced from the complete set of multinuclear NMR data (Table 4).

Formation of 1-silacyclobutene derivatives: Reactions of di(alkyn-1-yl)(chloro)silanes $2 \boldsymbol{a}, \boldsymbol{d}$ and $\mathbf{3 d}$ with 9-BBN

Reactions of di(alkyn-1-yl)(chloro)silanes with 9-BBN require less stringent reaction conditions (80$100{ }^{\circ} \mathrm{C}$, few hours or few days in some cases) using toluene or benzene as solvents. The reactions proceed 

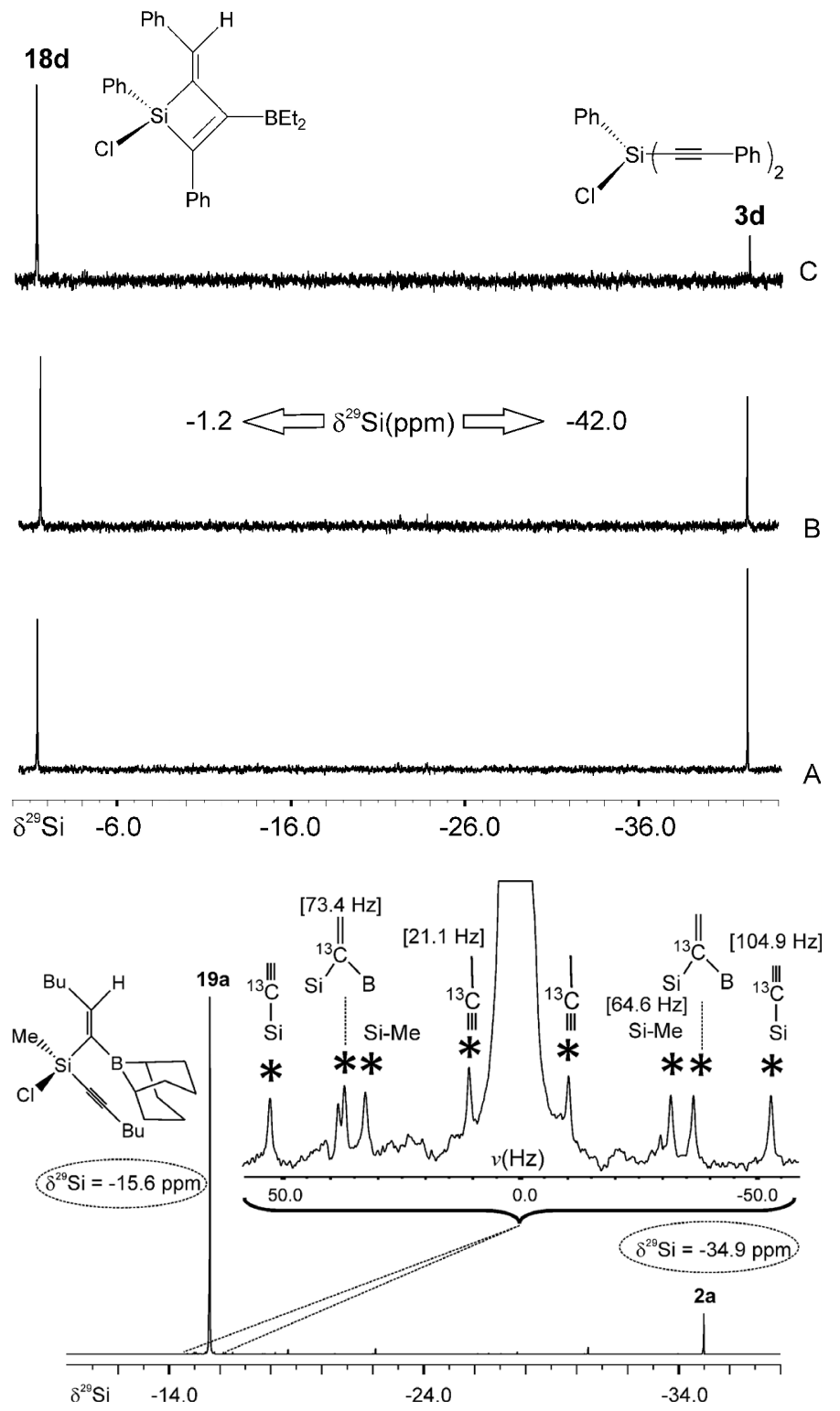

Fig. 4. Monitoring of the reaction of $\mathbf{3 d}$ with $\mathrm{BEt}_{3}$ by $59.6 \mathrm{MHz}{ }^{29} \mathrm{Si}$ NMR spectroscopy (A) after $3 \mathrm{~d}$; (B) after $9 \mathrm{~d}$; (C) after $15 \mathrm{~d}$. The reaction mixture contains only the starting silane $\mathbf{3 d}$ and the 1-silacyclobutene derivative 18d (ca. 9:1). No intermediate analogous to 19 and $\mathbf{2 0}$ were detected.

Fig. 5. 59.6 MHz ${ }^{29} \mathrm{Si}\left\{{ }^{1} \mathrm{H}\right\}$ NMR spectrum (refocused INEPT) of the reaction mixture containing the starting silane $\mathbf{2 a}$ and the intermediate 19a. Expansion is given for the signal belonging to $19 a$, showing ${ }^{13} \mathrm{C}$ satellites, owing to ${ }^{n} J\left({ }^{13} \mathrm{C},{ }^{29} \mathrm{Si}\right), n=1,2$.

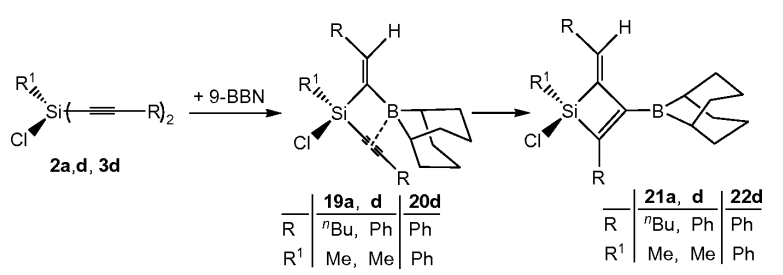

via 1,2-hydroboration of one $\mathrm{Si}-\mathrm{C} \equiv \mathrm{C}$ - bond to give at first the alkenyl(alkyn-1-yl)silanes $\mathbf{1 9}$ and $\mathbf{2 0}$ as intermediates. These are fairly stable $[17,18]$ and were fully characterized by multinuclear NMR spectroscopy (Table 4; Fig. 5). On further heating 19 and 20 undergo intramolecular 1,1-vinylboration affording the 1-silacyclobutene derivatives $\mathbf{2 1}$ and 22 (Scheme 6; Fig. 6). The NMR data obtained for 21 and 22 compare well with those reported previously for analogous heterocycles [18]. The reactions shown in Scheme

Scheme 6. Reactions of di(alkyn-1-yl)(chloro)silanes 2a, d and 3d with 9-BBN.

6 were carried out to support the data obtained for the four-membered heterocycles 16-18 (Scheme 5), 

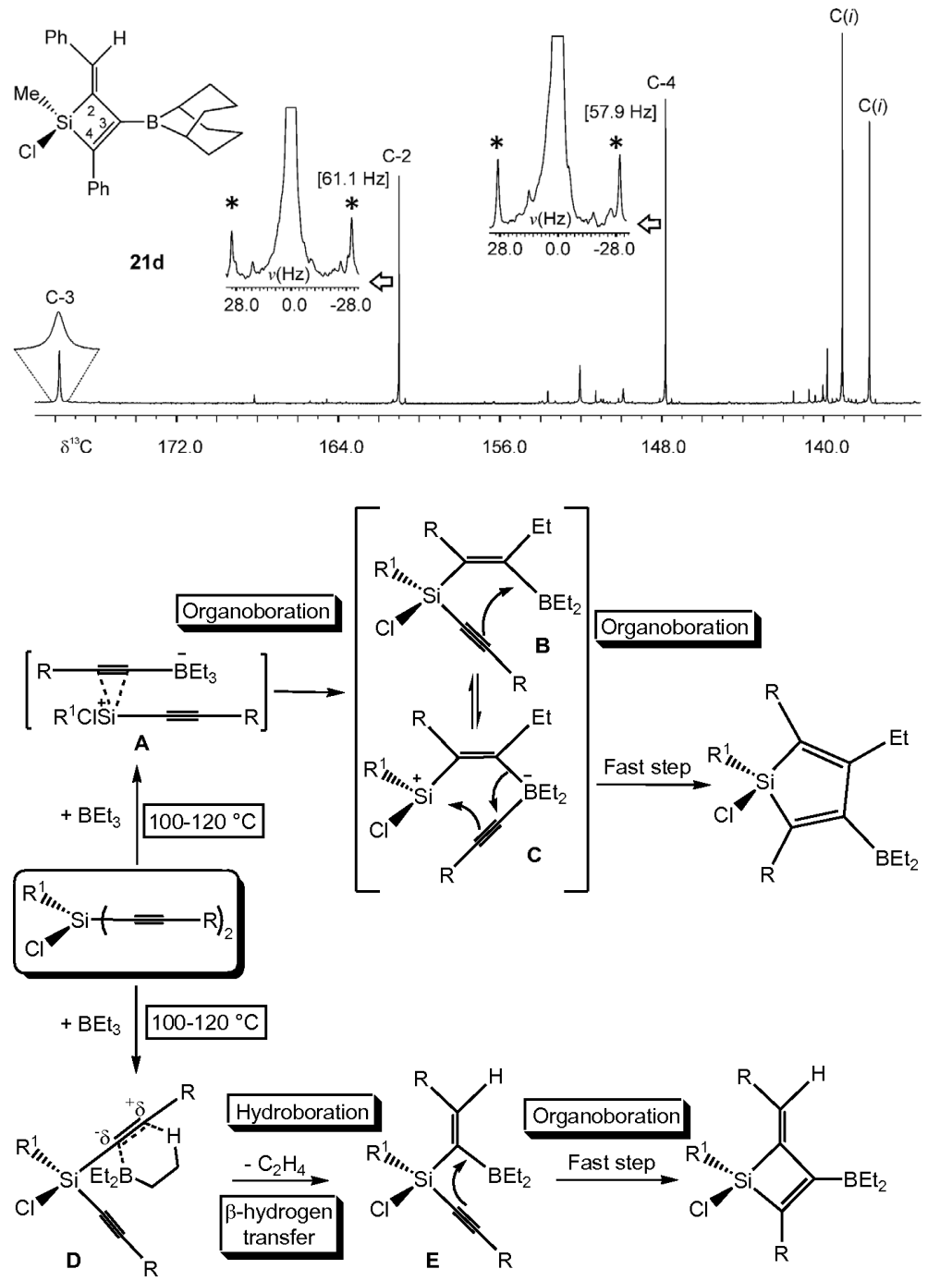

Fig. 6. Part of the $100.5 \mathrm{MHz}{ }^{13} \mathrm{C}\left\{{ }^{1} \mathrm{H}\right\}$ NMR spectrum of 21d (measured at $23{ }^{\circ} \mathrm{C}, \quad c a .15 \% \quad(\mathrm{v} / \mathrm{v})$ solution in $\mathrm{C}_{6} \mathrm{D}_{6}$ ). Signals for 1-silacyclobutene ring carbons (C-2 and $\mathrm{C}-4)$ are evident from ${ }^{29} \mathrm{Si}$ satellites for ${ }^{1} \mathrm{~J}\left({ }^{13} \mathrm{C},{ }^{29} \mathrm{Si}\right)$, while that of $\mathrm{C}-3$ linked to the boron atom is typically broad [21].
Scheme 7. Two alternative reaction pathways leading either to siloles or 1-silacyclobutene derivatives. where $\mathrm{BEt}_{3}$ served unexpectedly as a hydroborating reagent.

\section{Reaction mechanism}

The proposed mechanisms for the formation of siloles and 1-silacyclobutene derivatives are summarized in Scheme 7. Clearly, the product distribution depends on the $\mathrm{Si}-\mathrm{Cl}$ and $\mathrm{C} \equiv \mathrm{C}-\mathrm{R} / \mathrm{R}^{\prime}$ functions. The silanes bearing $\mathrm{R}=\mathrm{R}^{\prime}=\mathrm{Ph}$ open the way to 1 silacyclobutene derivatives. We propose a transition state $\mathbf{D}$, containing a six-membered cycle, and suggests the ability of the $\mathrm{C} \equiv \mathrm{C}$-Ph group to delocalize a positive charge plays an important role in its stabilization. Starting from $\mathbf{D}$, the intermediate $\mathbf{E}$ is formed by $\beta$-hydrogen transfer and elimination of ethene. Intramolecular rearrangement by 1,1-vinylboration, similar to the formation of the siloles (from C), leads from $\mathbf{E}$ towards the 1-silacyclobutene derivatives.

\section{NMR spectroscopic studies}

The ${ }^{11} \mathrm{~B},{ }^{13} \mathrm{C}$ and ${ }^{29} \mathrm{Si}$ NMR data for siloles (7-9, 13-15), alkenyl(alkyn-1-yl)silane intermediates (19, 20) and 1-silacyclobutene derivatives (16-18, 21, 22) are summarized in Tables $2-4$, respectively. The ${ }^{1} \mathrm{H}$ NMR data are listed in the Experimental Section. The data sets are in full agreement with the proposed structures. Both siloles and 1-silacyclobutenes can readily be identified by their characteristic NMR 
parameters (for comparison see Figs. 1, 2 and 6). The chemical shifts $\delta^{11} \mathrm{~B}$ for intermediates (i.e. 19 and 20; $\delta=82 \pm 1$ ) and all products were observed in the expected range typical of triorganoboranes without significant $\mathrm{BC}(\mathrm{pp}) \pi$ interactions $[19,20]$. The siloles and 1-silacyclobutenes possess well distinguishable ${ }^{13} \mathrm{C}$ NMR data. Most ${ }^{13} \mathrm{C}$ NMR signals could be readily assigned by their ${ }^{29} \mathrm{Si}$ satellites $\left[{ }^{1} J\left({ }^{29} \mathrm{Si},{ }^{13} \mathrm{C}\right)\right.$ and $\left.{ }^{2} J\left({ }^{29} \mathrm{Si},{ }^{13} \mathrm{C}\right)\right]$ or by the typical increase in the line widths owing to partially relaxed one-bond ${ }^{13} \mathrm{C}-{ }^{11} \mathrm{~B}$ spin-spin coupling [21]. Because of their simplicity (Figs. 3,4), ${ }^{29} \mathrm{Si}$ NMR spectra are helpful in monitoring the reactions, and $\delta^{29} \mathrm{Si}$ data are markedly different for siloles and 1-silacyclobutene derivatives (Tables 2 and 3 ). In the ${ }^{1} \mathrm{H}$ NMR spectra (e.g. 16d, 17d, 18d), a singlet for an olefinic proton $[\mathrm{C}=\mathrm{CH}(\mathrm{Ph})]$ and the $\mathrm{ab}$ sence of signals for the $=\mathrm{C}$-Et group in the aliphatic region clearly show that 1,2-hydroboration has taken place.

\section{Conclusions}

1,1-Ethylboration of di(alkyn-1-yl)(chloro)silanes is an efficient method for the preparation of siloles bearing substituents on the silicon atom such as $\mathrm{Si}-\mathrm{Cl}$ and $\mathrm{Si}-\mathrm{H}$. In comparison to other reported methods [22] this process is fairly straightforward. In particular the $\mathrm{H}(\mathrm{Cl}) \mathrm{Si}$ - group in the new siloles, almost without precedent, is promising for further transformations. The role of the $\mathrm{Si}-\mathrm{Cl}$ function for the stability of the $\mathrm{Si}-\mathrm{C} \equiv$ bond is evident from a series of reactions where $\mathrm{BEt}_{3}$ acts as hydroborating reagent leading to 1-silacyclobutene derivatives. In this context, the influence of the phenyl group at the $\mathrm{C} \equiv \mathrm{C}$ bond is striking.

\section{Experimental Section}

All preparative work and handling of air-sensitive chemicals were carried out by observing necessary precautions to exclude traces of oxygen and moisture. Trichlorosilane, trichloro(methyl)silane, trichloro(phenyl)silane, 1-hexyne, 3,3dimethyl-but-1-yne, ethynylbenzene, trimethylsilylethyne, $n$-butyllithium in hexane $(1.6 \mathrm{M})$, triethylborane $\left(\mathrm{BEt}_{3}\right), 9$ borabicyclo[3.3.1]nonane (9-BBN) were commercial products and were used without further purification. NMR spectra: Bruker ARX $250 \mathrm{MHz}$ or Varian Inova $300 \mathrm{MHz}$ and $400 \mathrm{MHz}$ spectrometers $\left(23 \pm 1^{\circ} \mathrm{C}\right)$, all equipped with multinuclear units, using $\mathrm{C}_{6} \mathrm{D}_{6}$ solutions ( $\left.c a .15-20 \% \mathrm{v} / \mathrm{v}\right)$ in $5 \mathrm{~mm}$ tubes. Chemical shifts are given with respect to $\mathrm{SiMe}_{4}$ $\left[\delta^{1} \mathrm{H}\left(\mathrm{C}_{6} \mathrm{D}_{5} \mathrm{H}\right)=7.15, \delta^{13} \mathrm{C}\left(\mathrm{C}_{6} \mathrm{D}_{6}\right)=128.0, \delta^{29} \mathrm{Si}=0\right.$ for $\mathrm{SiMe}_{4}$ with $\left.\Xi\left({ }^{29} \mathrm{Si}\right)=19.867187 \mathrm{MHz}\right]$, and $\delta^{11} \mathrm{~B}=0$ for $\mathrm{BF}_{3}-\mathrm{OEt}_{2}$ with $\Xi\left({ }^{11} \mathrm{~B}\right)=32.083971 \mathrm{MHz} .{ }^{29} \mathrm{Si} \mathrm{NMR}$ spectra were recorded using the refocused INEPT pulse sequence with ${ }^{1} \mathrm{H}$ decoupling [23], based either on ${ }^{1} J\left({ }^{29} \mathrm{Si},{ }^{1} \mathrm{H}\right)$ $\approx 280 \mathrm{~Hz},{ }^{3} J\left({ }^{29} \mathrm{SiC}=\mathrm{C}^{1} \mathrm{H}\right) \approx 30-35 \mathrm{~Hz},{ }^{2} J\left({ }^{29} \mathrm{Si},{ }^{1} \mathrm{H}(\mathrm{SiMe})\right)$ or ${ }^{3} J\left({ }^{29} \mathrm{Si},{ }^{1} \mathrm{H}(\mathrm{SiPh})\right) \approx 7 \mathrm{~Hz}$ (after optimization of the respective refocusing delays).

\section{Synthesis of di(alkyn-1-yl)(chloro)silanes 1-6}

To a freshly prepared suspension of $\mathrm{Li}-\mathrm{C} \equiv \mathrm{C}-{ }^{n} \mathrm{Bu}$ (61 mmol) in hexane $(50 \mathrm{~mL})$, trichlorosilane $\mathrm{HSiCl}_{3}$ $(1.9 \mathrm{~mL}, 19.3 \mathrm{mmol})$ was added slowly at $-78{ }^{\circ} \mathrm{C}$. The reaction mixture was allowed to reach r.t. Insoluble materials were filtered off, and all readily volatile materials were removed under reduced pressure $\left(10^{-2}\right.$ Torr). The oily residue left was analyzed to contain a mixture of $\mathrm{HCl}_{2} \mathrm{Si}-\mathrm{C} \equiv \mathrm{C}-\mathrm{Ph}$, $\mathrm{HClSi}(\mathrm{C} \equiv \mathrm{C}-\mathrm{Ph})_{2}(\mathbf{1 a})$ and $\mathrm{HSi}(\mathrm{C} \equiv \mathrm{C}-\mathrm{Ph})_{3}$, and fractional distillation gave pure 1a as a colorless oil. The same procedure was followed for the syntheses of the analogous silanes $\mathbf{1 b}-\mathbf{d}, \mathbf{2 a}, \mathbf{d}$ and $\mathbf{3 d}$. A solution of $\mathrm{HCl}_{2} \mathrm{Si}-\mathrm{C} \equiv \mathrm{C}-{ }_{-}{ }^{t} \mathrm{Bu}$ (lighter fraction of the mixture containing 1b) in hexane $(10 \mathrm{~mL})$ was added to a freshly prepared $\mathrm{Li}-\mathrm{C} \equiv \mathrm{C}-{ }^{n} \mathrm{Bu}$ suspension at $-78^{\circ} \mathrm{C}$. The reaction mixture was slowly warmed to $\mathrm{r}$.t. and was stirred for $1 \mathrm{~h}$. The work-up procedure as described above gave the pure silane $\mathbf{4 a}$ as a colorless oil (yield $43.1 \%$ ). The same procedure was adopted for the synthesis of silanes $\mathbf{5 c}$ (yield $49 \%$ ) and $\mathbf{6 c}$ (yield $37.3 \%$ ).

1a: B.p. $=85^{\circ} \mathrm{C} / 2 \times 10^{-2}$ Torr. $-{ }^{1} \mathrm{H}$ NMR data (250 MHz): $\delta=0.7,1.2,1.9\left(\mathrm{t}, \mathrm{m}, \mathrm{t}, 18 \mathrm{H},{ }^{n} \mathrm{Bu}\right), 5.2(\mathrm{~s}$, $\left.1 \mathrm{H},{ }^{1} J\left({ }^{29} \mathrm{Si},{ }^{1} \mathrm{H}\right)=276.1 \mathrm{~Hz}, \mathrm{Si}-\mathrm{H}\right) . \quad-\operatorname{IR}\left(\mathrm{C}_{6} \mathrm{D}_{6}\right): v=2185$ $(\mathrm{C} \equiv \mathrm{C}), 2147(\mathrm{Si}-\mathrm{H}) \mathrm{cm}^{-1}$.

1b: B. p. $=47^{\circ} \mathrm{C} / 1.8 \times 10^{-1}$ Torr. $-{ }^{1} \mathrm{H} \mathrm{NMR}(250 \mathrm{MHz})$ : $\delta=1.0\left(\mathrm{~s}, 18 \mathrm{H},{ }^{t} \mathrm{Bu}\right), 5.3\left(\mathrm{~s}, 1 \mathrm{H},{ }^{1} J\left({ }^{29} \mathrm{Si},{ }^{1} \mathrm{H}\right)=274.2 \mathrm{~Hz}, \mathrm{Si}-\right.$ $\mathrm{H}) .-\mathrm{IR}\left(\mathrm{C}_{6} \mathrm{D}_{6}\right): v=2158(\mathrm{C} \equiv \mathrm{C}), 2128(\mathrm{Si}-\mathrm{H}) \mathrm{cm}^{-1}$.

1c: B. p. $=58{ }^{\circ} \mathrm{C} / 8.3 \times 10^{-2}$ Torr. $-{ }^{1} \mathrm{H} \mathrm{NMR}(250 \mathrm{MHz})$ : $\delta=-0.04\left(\mathrm{~s}, 18 \mathrm{H}, \mathrm{SiMe}_{3}\right), 5.1\left(\mathrm{~s}, 1 \mathrm{H},{ }^{1} J\left({ }^{29} \mathrm{Si},{ }^{1} \mathrm{H}\right)=\right.$ $279.0 \mathrm{~Hz}, \mathrm{Si}-\mathrm{H})$.

1d: B.p. $=112{ }^{\circ} \mathrm{C} / 1.0 \times 10^{-3}$ Torr. $-{ }^{1} \mathrm{H}$ NMR (250 MHz): $\delta=5.4\left(\mathrm{~s}, 1 \mathrm{H},{ }^{1} J\left({ }^{29} \mathrm{Si},{ }^{1} \mathrm{H}\right)=280.9 \mathrm{~Hz}, \mathrm{Si}-\mathrm{H}\right)$, $6.8-7.0,7.2-7.3(\mathrm{~m}, \mathrm{~m}, 10 \mathrm{H}, \mathrm{Ph})$.

2a: B. p. $=83-85{ }^{\circ} \mathrm{C} / 2.8 \times 10^{-2}$ Torr. $-{ }^{1} \mathrm{H}$ NMR (400 MHz): $\delta=0.6\left(\mathrm{~s}, 3 \mathrm{H},{ }^{2} J\left({ }^{29} \mathrm{Si},{ }^{1} \mathrm{H}\right)=8.2 \mathrm{~Hz}, \mathrm{Si}-\mathrm{Me}\right)$, $0.5,1.1,1.7\left(\mathrm{t}, \mathrm{m}, \mathrm{t}, 18 \mathrm{H},{ }^{n} \mathrm{Bu}\right)$.

2d: B. p. $=145-150{ }^{\circ} \mathrm{C} / 9.1 \times 10^{-2}$ Torr. $-{ }^{1} \mathrm{H}$ NMR $(400 \mathrm{MHz}): \delta=0.5\left(\mathrm{~s}, 3 \mathrm{H},{ }^{2} J\left({ }^{29} \mathrm{Si},{ }^{1} \mathrm{H}\right)=8.0 \mathrm{~Hz}, \mathrm{Si}-\mathrm{Me}\right)$, 6.6, $7.1(\mathrm{~m}, \mathrm{~m}, 10 \mathrm{H}, \mathrm{Ph})$.

3d: B.p. $=192-196{ }^{\circ} \mathrm{C} / 0.14$ Torr. $-{ }^{1} \mathrm{H}$ NMR (400 MHz): $\delta=6.8,7.2,8.0$ (m, m, m, 15H, Si-Ph, Ph).

4a: B. p. $=44{ }^{\circ} \mathrm{C} / 1 \times 10^{-2}$ Torr. $-{ }^{1} \mathrm{H}$ NMR $(250 \mathrm{MHz})$ : $\delta=0.7,1.4,1.8\left(\mathrm{t}, \mathrm{m}, \mathrm{t}, 9 \mathrm{H},{ }^{n} \mathrm{Bu}\right), 1.0\left(\mathrm{~s}, 9 \mathrm{H},{ }^{t} \mathrm{Bu}\right), 5.2(\mathrm{~s}$, $\left.1 \mathrm{H},{ }^{1} \mathrm{~J}\left({ }^{29} \mathrm{Si},{ }^{1} \mathrm{H}\right)=273.5 \mathrm{~Hz}, \mathrm{Si}-\mathrm{H}\right)$.

5c: B. p. $=55{ }^{\circ} \mathrm{C} / 1 \times 10^{-2}$ Torr. $-{ }^{1} \mathrm{H}$ NMR $(250 \mathrm{MHz})$ : $\delta=0.00\left(\mathrm{~s}, 9 \mathrm{H}, \mathrm{SiMe}_{3}\right), 0.6,1.0-1.2,1.8\left(\mathrm{t}, \mathrm{m}, \mathrm{t}, 9 \mathrm{H},{ }^{n} \mathrm{Bu}\right)$, $5.2\left(\mathrm{~s}, 1 \mathrm{H},{ }^{1} \mathrm{~J}\left({ }^{29} \mathrm{Si},{ }^{1} \mathrm{H}\right)=275.8 \mathrm{~Hz}, \mathrm{Si}-\mathrm{H}\right)$. 
6c: B.p. $=78{ }^{\circ} \mathrm{C} / 1 \times 10^{-2}$ Torr. $-{ }^{1} \mathrm{H}$ NMR $(250 \mathrm{MHz})$ : $\delta=0.01\left(\mathrm{~s}, 9 \mathrm{H}, \mathrm{SiMe}_{3}\right), 6.8-7.0,7.2(\mathrm{~m}, 5 \mathrm{H}, \mathrm{Ph}), 5.2(\mathrm{~s}$, $\left.1 \mathrm{H},{ }^{1} \mathrm{~J}\left({ }^{29} \mathrm{Si},{ }^{1} \mathrm{H}\right)=279.1 \mathrm{~Hz}, \mathrm{Si}-\mathrm{H}\right)$.

\section{1,1-Ethylboration of silanes $1-6$, syntheses of siloles 7-9 and $13-15$}

General procedure: A Schlenk tube was charged with the solution of the respective di(alkyn-1-yl)silane and triethylborane in large excess (as the reagent as well as the solvent). The reaction solution was heated at $100-120{ }^{\circ} \mathrm{C}$ (oil bath temperature). The reaction was monitored by ${ }^{29} \mathrm{Si} \mathrm{NMR}$ spectroscopy. After it was complete, all volatile materials were removed under reduced pressure, and the remaining brown oily liquids (siloles) were studied by NMR spectroscopy. Except for the reaction time, the experimental procedure was the same for all siloles. Time required for reaction completion was $1 \mathrm{~d}(\mathbf{7 a}), 7 \mathrm{~d}(\mathbf{7 b}, \mathbf{8 a}), 4 \mathrm{~h}(\mathbf{7 c}), 10 \mathrm{~d}(\mathbf{7 d})$ and $20 \mathrm{~d}(\mathbf{9 a})$.

7a: $\quad$ B. p. $=120{ }^{\circ} \mathrm{C} / 1.0 \times 10^{-3}$ Torr. $-{ }^{1} \mathrm{H}$ NMR (250 MHz): $\delta=0.8,0.9,1.3,2.3\left(\mathrm{t}, \mathrm{t}, \mathrm{m}, \mathrm{t}, 18 \mathrm{H},{ }^{n} \mathrm{Bu}\right)$, $0.9,2.0$ (t, q, 5H, Et), 0.9, 1.6 (t, br, 10H, BEt 2 ), 5.5 (s, 1H, $\left.{ }^{1} J\left({ }^{29} \mathrm{Si},{ }^{1} \mathrm{H}\right)=237.4 \mathrm{~Hz}, \mathrm{Si}-\mathrm{H}\right)$.

7b: $\quad$ B.p. $=100{ }^{\circ} \mathrm{C} / 1.0 \times 10^{-3}$ Torr. $-{ }^{1} \mathrm{H}$ NMR $(250 \mathrm{MHz}): \delta=1.1,1.3\left(\mathrm{~s}, \mathrm{~s}, 18 \mathrm{H},{ }^{t} \mathrm{Bu}\right), 1.0,2.1(\mathrm{t}, \mathrm{q}, 5 \mathrm{H}$, Et), 1.1, $1.6\left(\mathrm{t}, \mathrm{br}, 10 \mathrm{H}, \mathrm{BEt}_{2}\right), 5.4\left(\mathrm{~s}, 1 \mathrm{H},{ }^{1} J\left({ }^{29} \mathrm{Si},{ }^{1} \mathrm{H}\right)=\right.$ $222.6 \mathrm{~Hz}, \mathrm{Si}-\mathrm{H})$.

7c: ${ }^{1} \mathrm{H}$ NMR (400 MHz): $\delta=0.2,0.3\left(\mathrm{~s}, \mathrm{~s}, 18 \mathrm{H}, \mathrm{SiMe}_{3}\right)$, 0.9, 2.2 (t, q, 5H, Et), 0.9, 1.0, 1.3 (t, t, m, 10H, BEt 2 ), 5.6 (s, $\left.1 \mathrm{H},{ }^{1} J\left({ }^{29} \mathrm{Si},{ }^{1} \mathrm{H}\right)=222.4 \mathrm{~Hz}, \mathrm{Si}-\mathrm{H}\right)$.

7d: ${ }^{1} \mathrm{H}$ NMR $(250 \mathrm{MHz}): \delta=0.9,2.1$ (t, q, 5H, Et), $1.1,1.2-1.5\left(\mathrm{t}, \mathrm{m}, 10 \mathrm{H}, \mathrm{BEt}_{2}\right), 5.6\left(\mathrm{~s}, 1 \mathrm{H},{ }^{1} J\left({ }^{29} \mathrm{Si},{ }^{1} \mathrm{H}\right)=\right.$ $234.9 \mathrm{~Hz}, \mathrm{Si}-\mathrm{H}), 6.8-7.0,7.1-7.3(\mathrm{~m}, \mathrm{~m}, 10 \mathrm{H}, \mathrm{Ph})$.

8a: ${ }^{1} \mathrm{H}$ NMR (400 MHz): $\delta=0.5$ (s, 3H, Si-Me), 0.8, 0.8, 1.3, $2.2\left(\mathrm{t}, \mathrm{t}, \mathrm{m}, \mathrm{m}, 18 \mathrm{H},{ }^{n} \mathrm{Bu}\right), 1.0,2.3$ (t, m, 5H, Et), 0.9, 1.5 (t, m, 10H, BEt 2 ).

9a: ${ }^{1} \mathrm{H}$ NMR $(400 \mathrm{MHz}): \delta=0.6-1.4,1.8-2.5$ (overlapping multiplets of ${ }^{n} \mathrm{Bu}, \mathrm{BEt}_{2}$ and Et groups), 7.1, 7.7 (m, $\mathrm{m}, 5 \mathrm{H}, \mathrm{Si}-\mathrm{Ph})$.

13a: ${ }^{1} \mathrm{H}$ NMR (250 MHz): $\delta=0.7,1.2-1.3,1.9(\mathrm{t}, \mathrm{m}, \mathrm{m}$, $\left.9 \mathrm{H},{ }^{n} \mathrm{Bu}\right), 1.1\left(\mathrm{~s}, 9 \mathrm{H},{ }^{t} \mathrm{Bu}\right), 1.1,2.2$ (m, q, 5H, Et), 1.1, $1.2-$ $1.3\left(\mathrm{~m}, \mathrm{~m}, 10 \mathrm{H}, \mathrm{BEt}_{2}\right), 5.3\left(\mathrm{~s}, 1 \mathrm{H},{ }^{1} \mathrm{~J}\left({ }^{29} \mathrm{Si},{ }^{1} \mathrm{H}\right)=221.9 \mathrm{~Hz}\right.$, $\mathrm{Si}-\mathrm{H})$.

13a': ${ }^{1} \mathrm{H}$ NMR $(250 \mathrm{MHz}): \delta=5.3(\mathrm{~s}, 1 \mathrm{H}, \mathrm{Si}-\mathrm{H})$

14a: ${ }^{1} \mathrm{H}$ NMR (250 MHz): $\delta=0.3\left(\mathrm{~s}, 9 \mathrm{H}, \mathrm{SiMe}_{3}\right), 0.8$, $1.0-1.2,2.2\left(\mathrm{t}, \mathrm{m}, \mathrm{t}, 9 \mathrm{H},{ }^{n} \mathrm{Bu}\right), 0.9,2.0-2.1$ (t, m, 5H, $\mathrm{Et}), 1.0,1.3\left(\mathrm{~m}, \mathrm{~m}, 10 \mathrm{H}, \mathrm{BEt}_{2}\right), 5.5\left(\mathrm{~s}, 1 \mathrm{H},{ }^{1} \mathrm{~J}\left({ }^{29} \mathrm{Si},{ }^{1} \mathrm{H}\right)=\right.$ $222.3 \mathrm{~Hz}, \mathrm{Si}-\mathrm{H})$.

14a': ${ }^{1} \mathrm{H}$ NMR (250 MHz): $\delta=0.2\left(\mathrm{~s}, 9 \mathrm{H}, \mathrm{SiMe}_{3}\right), 5.5$ (s, 1H, Si-H).

15c: ${ }^{1} \mathrm{H}$ NMR $(250 \mathrm{MHz}): \delta=0.3\left(\mathrm{~s}, 9 \mathrm{H}, \mathrm{SiMe}_{3}\right), 1.0$, $2.4(\mathrm{t}, \mathrm{q}, 5 \mathrm{H}, \mathrm{Et}), 0.9,1.4\left(\mathrm{t}, \mathrm{q}, 10 \mathrm{H}, \mathrm{BEt}_{2}\right), 5.5(\mathrm{~s}, 1 \mathrm{H}$, $\left.{ }^{1} J\left({ }^{29} \mathrm{Si},{ }^{1} \mathrm{H}\right)=226.1 \mathrm{~Hz}, \mathrm{Si}-\mathrm{H}\right), 7.0-7.1,7.4-7.6(\mathrm{~m}, \mathrm{~m}, 5 \mathrm{H}$, $\mathrm{Ph})$.

15c': ${ }^{1} \mathrm{H}$ NMR (250 MHz): $\delta=0.3\left(\mathrm{~s}, 9 \mathrm{H}, \mathrm{SiMe}_{3}\right), 5.2$ (s, 1H, Si-H).

\section{Alkenyl(alkyn-1-yl)silanes 10a, 11c and $12 c$}

Silanes 10a, 11c and 12c were present as side products accompanying the siloles $\mathbf{1 3} \mathbf{- 1 5}$.

10a: ${ }^{1} \mathrm{H}$ NMR $(250 \mathrm{MHz}): \delta=5.6\left(\mathrm{~s}, 1 \mathrm{H},{ }^{1} \mathrm{~J}\left({ }^{29} \mathrm{Si},{ }^{1} \mathrm{H}\right)=\right.$ $248.6 \mathrm{~Hz}, \mathrm{Si}-\mathrm{H}) . \quad-{ }^{13} \mathrm{C}$ NMR: $\delta=82.9(\mathrm{Si}-\mathrm{C} \equiv), 119.2$ $(\equiv \mathrm{C}), 30.4\left({ }^{t} \mathrm{Bu}-\mathrm{Me}_{3}\right) . \quad{ }^{29} \mathrm{Si} \mathrm{NMR}: \delta=-39.8$.

11c: ${ }^{29} \mathrm{Si} \mathrm{NMR}: \delta=-42.6 \mathrm{ppm},{ }^{1} J\left({ }^{29} \mathrm{Si},{ }^{1} \mathrm{H}\right)=246.6 \mathrm{~Hz}$.

12c: ${ }^{1} \mathrm{H}$ NMR $(250 \mathrm{MHz}): \delta=0.2\left(\mathrm{~s}, 9 \mathrm{H}, \mathrm{SiMe}_{3}\right), 5.6$ $\left(\mathrm{s}, 1 \mathrm{H},{ }^{1} J\left({ }^{29} \mathrm{Si},{ }^{1} \mathrm{H}\right)=244.8 \mathrm{~Hz}, \mathrm{Si}-\mathrm{H}\right) .-{ }^{13} \mathrm{C}$ NMR: $\delta=$ $1.3\left(\mathrm{SiMe}_{3}\right), 89.9$ ( $\left.\mathrm{Si}-\mathrm{C} \equiv\right), 108.7$ (三C), 139.3 (=C), 191.6 (br, $\mathrm{C}=), 123.6,128.5,129.5,132.3(\mathrm{Ph}) .{ }^{29} \mathrm{Si} \mathrm{NMR}: \delta=$ $-43.0,-5.1\left({ }^{29} \mathrm{SiMe}_{3}\right)$.

Hydroboration of di(alkyn-1-yl)(chloro)silanes $\mathbf{1 - 3}$ using $\mathrm{BEt}_{3}$ as hydroborating reagent

A mixture of the silane $\mathrm{MeSiCl}(\mathrm{C} \equiv \mathrm{C}-\mathrm{Ph})_{2}, \mathbf{2 d}(0.5 \mathrm{~g}$, $1.8 \mathrm{mmol})$ and $\mathrm{BEt}_{3}(1 \mathrm{~mL}$, in slight excess $)$ was sealed in an NMR tube and kept at $100-120{ }^{\circ} \mathrm{C}$ in an oil bath. The progress of the reaction was monitored by ${ }^{29} \mathrm{Si}$ NMR spectroscopy, and after $12 \mathrm{~d}$ the reaction was found to be complete. The NMR tube was cooled in liquid $\mathrm{N}_{2}$ and opened. Excess of $\mathrm{BEt}_{3}$ and other volatiles were removed under reduced pressure $\left(10^{-2}\right.$ Torr), and the oily residue was identified as 17d ( $c a .90 \%$ pure according to ${ }^{1} \mathrm{H}$ NMR spectra). The procedure for $\mathbf{1 8 d}$ was identical to $\mathbf{1 7 d}$, except that heating lasted for $15 \mathrm{~d}$ and the reaction was complete only to ca. $90 \%$ (Fig. 4).

17d: ${ }^{1} \mathrm{H}$ NMR $(400 \mathrm{MHz}): \delta=0.7(\mathrm{~s}, 3 \mathrm{H}, \mathrm{Si}-\mathrm{Me})$, $0.9,1.4\left(\mathrm{t}, \mathrm{m}, 10 \mathrm{H}, \mathrm{BEt}_{2}\right), 6.4\left(\mathrm{~s}, 1 \mathrm{H},{ }^{3} \mathrm{~J}\left({ }^{1} \mathrm{H},{ }^{29} \mathrm{Si}\right)=\right.$ $19.3 \mathrm{~Hz},=\mathrm{CH}), 6.9-7.4(\mathrm{~m}, 10 \mathrm{H}, \mathrm{Ph}, \mathrm{Ph})$.

18d: ${ }^{1} \mathrm{H}$ NMR (400 MHz): $\delta=1.0,1.5\left(\mathrm{t}, \mathrm{m}, 10 \mathrm{H}, \mathrm{BEt}_{2}\right)$, $6.5\left(\mathrm{~s}, 1 \mathrm{H},{ }^{3} J\left({ }^{1} \mathrm{H},{ }^{29} \mathrm{Si}\right)=21.4 \mathrm{~Hz},=\mathrm{CH}\right), 6.8-7.4(\mathrm{~m}, 15 \mathrm{H}$, $\mathrm{Si}-\mathrm{Ph}, \mathrm{Ph})$

Hydroboration of di(alkyn-1-yl)(chloro)silanes $\mathbf{2 a}$, $\boldsymbol{d}$ and $\mathbf{3 d}$ using 9-BBN

A solution of silane $2 \mathrm{a}(0.74 \mathrm{~g}, 3.1 \mathrm{mmol})$ in $\mathrm{C}_{6} \mathrm{D}_{6}$ $(1.5 \mathrm{~mL})$ was mixed with the crystalline 9-BBN dimer $(0.387 \mathrm{~g}, 3.1 \mathrm{mmol})$. The mixture was heated to $80{ }^{\circ} \mathrm{C}$ for $20 \mathrm{~min}$. During this time 9-BBN was completely consumed (monitored by ${ }^{11} \mathrm{~B}$ NMR spectroscopy). The NMR data clearly indicated the formation of 19a. The 1,2-hydroboration of the silanes $\mathbf{2 d}$ and $\mathbf{3 d}$ was carried out in the same way leading to alkenyl(alkyn-1-yl)silanes 19d and 20d. 
19a: ${ }^{1} \mathrm{H}$ NMR $(400 \mathrm{MHz}): \delta=0.7\left(\mathrm{~s}, 3 \mathrm{H},{ }^{2} J\left({ }^{29} \mathrm{Si},{ }^{1} \mathrm{H}\right)=\right.$ $7.4 \mathrm{~Hz}, \mathrm{Si}-\mathrm{Me}), 0.7,0.9,1.2-1.3,2.0,2.5(\mathrm{t}, \mathrm{t}, \mathrm{m}, \mathrm{t}, \mathrm{m}$, $\left.18 \mathrm{H},{ }^{n} \mathrm{Bu}\right), 1.4,1.8-2.0(\mathrm{~m}, \mathrm{~m}, 14 \mathrm{H}, 9-\mathrm{BBN}), 7.0(\mathrm{t}, 1 \mathrm{H}$, $\left.{ }^{3} J\left({ }^{1} \mathrm{H},{ }^{1} \mathrm{H}\right)=7.3 \mathrm{~Hz},{ }^{3} \mathrm{~J}\left({ }^{29} \mathrm{Si},{ }^{1} \mathrm{H}\right)=21.1 \mathrm{~Hz},=\mathrm{CH}\right)$.

19d: ${ }^{1} \mathrm{H}$ NMR $(400 \mathrm{MHz}): \delta=0.3\left(\mathrm{~s}, 3 \mathrm{H},{ }^{2} J\left({ }^{29} \mathrm{Si},{ }^{1} \mathrm{H}\right)=\right.$ $7.7 \mathrm{~Hz}, \mathrm{Si}-\mathrm{Me}), 1.2,1.6-2.1$ (m, m, 14H, 9-BBN), 7.3, 7.1, 7.0, 6.7-6.8 (m, m, m, m, 10H, Ph), 7.9 (s, $1 \mathrm{H},{ }^{3} \mathrm{~J}\left({ }^{1} \mathrm{H},{ }^{29} \mathrm{Si}\right)=$ $21.7 \mathrm{~Hz},=\mathrm{CH})$.

20d: ${ }^{1} \mathrm{H}$ NMR (400 MHz): $\delta=1.4,1.9-2.2(\mathrm{~m}, \mathrm{~m}, 14 \mathrm{H}$, 9-BBN), 7.9, 7.6, 6.9-7.3 (m, m, m, 15H, Si-Ph, Ph), 8.2 (s, $\left.1 \mathrm{H},{ }^{3} \mathrm{~J}\left({ }^{29} \mathrm{Si},{ }^{1} \mathrm{H}\right)=21.4 \mathrm{~Hz},=\mathrm{CH}\right)$.

Syntheses of 1-silacyclobutene derivatives $21 a, d$ and $22 d$

Compounds 19 and 20 were heated at $80{ }^{\circ} \mathrm{C}$ to afford the 1-silacyclobutene derivatives 21a, 21d and 22d upon ring closure. The time required for complete rearrangement via intramolecular 1,1-vinylboration was $7 \mathrm{~d}$ (21a), $5 \mathrm{~d}$ (21d) and $12 \mathrm{~h}(\mathbf{2 2 d})$.

21a: ${ }^{1} \mathrm{H}$ NMR (400 MHz): $\delta=0.8$ (s, 3H, Si-Me), 0.8, $1.3,2.3\left(\mathrm{t}, \mathrm{m}, \mathrm{m}, 18 \mathrm{H},{ }^{n} \mathrm{Bu}\right), 1.3,1.8-1.9(\mathrm{~m}, \mathrm{~m}, 14 \mathrm{H}$, 9-BBN), $5.8\left(\mathrm{t}, 1 \mathrm{H},{ }^{3} J\left({ }^{1} \mathrm{H},{ }^{1} \mathrm{H}\right)=6.9 \mathrm{~Hz},{ }^{3} J\left({ }^{29} \mathrm{Si},{ }^{1} \mathrm{H}\right)=\right.$ $22.1 \mathrm{~Hz},=\mathrm{CH})$.

21d: ${ }^{1} \mathrm{H}$ NMR $(400 \mathrm{MHz}): \delta=0.4\left(\mathrm{~s}, 3 \mathrm{H},{ }^{2} J\left({ }^{29} \mathrm{Si},{ }^{1} \mathrm{H}\right)=\right.$ $7.1 \mathrm{~Hz}, \mathrm{Si}-\mathrm{Me}$ ), 1.2-2.1 (m, 14H, 9-BBN), 6.6-7.2 (m, $11 \mathrm{H}, \mathrm{Ph},=\mathrm{CH})$.

22d: ${ }^{1} \mathrm{H}$ NMR $(400 \mathrm{MHz}): \delta=1.4-2.0(\mathrm{~m}, 14 \mathrm{H}$, 9-BBN), 6.8-7.2, 7.4, 7.9 (m, m, m, 16H, Si-Ph, Ph, =CH).

\section{Acknowledgements}

We thank the Deutsche Forschungsgemeinschaft for supporting this work. E. K. is grateful to DAAD and HEC (Pakistan) for a scholarship.
[1] a) K. Oshima, Bull. Chem. Soc. Japan 2008, 81, 1; b) M. Kimura, Y. Tamaru, Topics Curr. Chem. 2007, 279, 173; c) Y. Tamaru, Organomet. News 2007, 12 ; d) T. Ukon, T. Harada, Eur. J. Org. Chem. 2008, 4405; e) D. S. Lim, S. C. Ngo, S. G. Lal, K. E. Minnich, J. T. Welch, Tetrahedron Lett. 2008, 49, 5662; f) C. Billaud, J.-P. Goddard, T. Le Gall, C. Mioskowski, Tetrahedron Lett. 2003, 44, 4451; g) J. F. Geisz, D. J. Friedman, S. Kurtz, R. C. Reedy, G. Barber, J. Electr. Mat. 2001, 30, 1387; h) S. Deprele, J.-C. Montchamp, J. Org. Chem. 2001, 66, 6745; i) K. Nakamura, T. Sasaki, J. Solid State Chem. 2000, 154, 101; j) A. Shifman, N. Palani, S. Hoz, Angew. Chem. 2000, 112, 974; Angew. Chem. Int. Ed. 2000, 39, 944; k) R. Köster, W. Schüssler, R. Boese, M. Herberhold, S. Gerstmann, B. Wrackmeyer, Chem. Ber. 1996, 129, 503; 1) P. Binger, R. Köster, Inorg. Synth. 1974, 15, 136; m) R. Köster, W. Fenzl, Liebigs Ann. Chem. 1974, 69.

[2] R. Köster, G. Seidel, G. Süß, B. Wrackmeyer, Chem. Ber. 1993, 126, 1107.

[3] a) B. Wrackmeyer, Coord. Chem. Rev. 1995, 145, 125; b) B. Wrackmeyer, Heteroatom Chem. 2006, 17, 188; c) B. Wrackmeyer, O.L. Tok, Comprehensive Heterocyclic Chemistry III, (Eds.: A. R. Katritzky, C. A. Ramsden, E. F. V. Scriven, R. J. K. Taylor), Elsevier, Oxford, 2008, pp. 1181-1223.

[4] a) B. Wrackmeyer, W. Milius, M. H. Bhatti, S. Ali, J. Organomet. Chem. 2003, 665, 196; b) B. Wrackmeyer, O.L. Tok, M.H. Bhatti, S. Ali, Coll. Czech. Chem. Commun. 2002, 67, 822; c) B. Wrackmeyer, O. L. Tok, K. Shahid, S. Ali, Inorg. Chim. Acta 2004, $357,1103$.

[5] a) B. Wrackmeyer, G. Kehr, J. Süß, Chem. Ber. 1993, 126, 2221; b) B. Wrackmeyer, J. Süß, Z. Naturforsch. 2002, $57 b, 741$.
[6] a) B. Wrackmeyer, O. L. Tok, A. Khan, A. Badshah, Z. Naturforsch. 2005, 60b, 251; b) B. Wrackmeyer, O. L. Tok, A. Khan, A. Badshah, Appl. Organomet. Chem, 2005, 19, 1249.

[7] A. Stock, F. Zeidler, Ber. Deutsch. Chem. Ges. 1921, $54 B, 531$.

[8] a) L. Rosenblum, J. Am. Chem. Soc. 1955, 77, 5016; b) R. Köster, Liebigs Ann. Chem. 1958, 618, 31; c) E. C. Ashby, J. Am. Chem. Soc. 1959, 81, 4791; d) P. F. Winternitz, A. A. Carotti, J. Am. Chem. Soc. 1960, 82, 2430.

[9] R. Köster, G. Benedikt, W. Larbig, K. Reinert, G. Rotermund, Angew. Chem. 1963, 75, 1079.

[10] R. Köster, W. Larbig, G. W. Rotermund, Liebigs Ann. Chem. 1965, 682, 21.

[11] R. Köster in Houben-Weyl Methoden der Organischen Chemie, Vol 13/3c, Ed.: R. Köster), Thieme Stuttgart, 1984, p. 217.

[12] E. Abuin, J. Grotewold, E. A. Lissi, M.C. Vara, J. Chem. Soc. B 1968, 1044.

[13] B. Wrackmeyer, E. Khan, S. Bayer, K. Shahid, Z. Naturforsch. 2007, 62b, 1174.

[14] B. Wrackmeyer, E. Khan, W. Milius, Z. Naturforsch. 2008, 63b, 1267.

[15] a) W. E. Davidsohn, M. C. Henry, Chem. Rev. 1967, 67, 73; b) L. Brandsma, Preparative Acetylenic Chemistry, ( $2^{\text {nd }}$ ed.), Elsevier, Amsterdam, 1988; c) L. Brandsma, Synthesis of Acetylenes, Allenes, Cumulenes - Methods and Techniques, Elsevier, Amsterdam, 2004.

[16] a) H. Lang, U. Lay, L. Zsolnai, J. Organomet. Chem. 1991, 417, 377; b) C. K. Frisch, B. R. Young, J. Am. Chem. Soc. 1952, 74, 4853; c) N. O. Florensova, A. B. Sokolov, I. L. Volkova, Izvest. Akad. Nauk SSSR, Ser. Khim. 1973, 1390.

[17] B. Wrackmeyer, H.E. Maisel, E. Molla, A. Mot- 
talib, A. Badshah, Appl. Organomet. Chem. 2003, 17,465 .

[18] B. Wrackmeyer, E. Khan, R. Kempe, Appl. Organomet. Chem. 2007, 21, 39.

[19] a) B. Wrackmeyer, E. Khan, R. Kempe, Z. Naturforsch. 2007, 62b, 75; b) B. Wrackmeyer, A. Badshah, E. Molla, A. Mottalib, J. Organomet. Chem. 1999, 98, 584; c) B. Wrackmeyer, K. Shahid, S. Ali, Appl. Organomet. Chem. 2005, 19, 377; d) B. Wrackmeyer, W. Milius, M. H. Bhatti, S. Ali, J. Organomet. Chem. 2003, 72, 669 .

[20] H. Nöth, B. Wrackmeyer, Nuclear Magnetic Resonance Spectroscopy of Boron Compounds in NMR -
Basic Principles and Progress, Vol. 14, Eds.: P. Diehl, E. Fluck, R. Kosfeld) Springer, Berlin, 1978.

[21] a) B. Wrackmeyer, Progr. NMR Spectrosc. 1979, 12, 227; b) B. Wrackmeyer, Annu. Rep. NMR Spectrosc. 1988, 20,61 .

[22] a) J. B.-Wilking, Y. Zhang, J. Y. Corey, N.P. Rath, J. Organomet. Chem. 2008, 693, 1233; b) H. Sohn, J. Organomet. Chem. 2004, 689, 134.

[23] a) G. A. Morris, R. Freeman, J. Am. Chem. Soc. 1979, 101, 760; b) G. A. Morris, J. Am. Chem. Soc. 1980, 102, 428; c) G. A. Morris, J. Magn. Reson. 1980, 41, 185 ; d) D. P. Burum, R. R. Ernst, J. Magn. Reson. 1980, $39,163$. 